\title{
Earnings Quality and Book-to-Market in the Cross Section of Expected Returns
}

\author{
Vasiliki Athanasakou \\ Saint Mary's University, Canada \\ George Athanassakos \\ University of Western Ontario, Canada
}

\begin{abstract}
The purpose of this paper is to examine whether earnings quality contributes to the book-to- market's predictive power in the cross section of stock returns. Earnings quality is embedded in the value-growth effect given that retained earnings is a key part of the book value of equity. Earnings quality reflects the effects of managerial discretion on reported earnings, which has been shown to be associated with both risk and behavioral biases in asset pricing. Our results affirm the existence of a value premium and show that the value premium is more pronounced within poor earnings quality stocks. Moreover, we find that poor earnings quality contributes to the value premium mainly through the pricing of growth stocks. Our results suggest that the quality of reported earnings has an incremental role in shaping expected returns of value versus growth stocks. (JEL: G12, M41)
\end{abstract}

Keywords: value premium; earnings quality; earnings management; asset pricing

Article history: Received: 25 January 2019, Received in final revised form: 4 October 2019, Accepted: 15 October 2019, Available online: 21 November 2019

\section{Introduction}

In this paper, we examine whether earnings quality contributes to the

\footnotetext{
* We thank Theodore Sougiannis, Dimos Andronoudis, Jose Faias, and Sungbin Sohn for helpful comments and suggestions.

(Multinational Finance Journal, 2019, vol. 23, no. 3/4, pp. 169-210)

(C) Multinational Finance Society, a nonprofit corporation. All rights reserved.
} 
book-to-market's predictive power in the cross section of stock returns. Book-to-market's predictive power of stock returns is inextricably linked to earnings. Ball, Gerakos, Linnainmaa and Nikolaev (2019) make this link evident by highlighting retained earnings and contributed capital as the two main parts of the book value of equity, and showing that the earnings yield subsumes the book to market's predictive power. Fama and French (2015) also highlight the role of profitability in shaping asset prices, by showing that profitability is a priced risk factor that subsumes the value factor. Retained earnings cumulate a firm's profitability, but also the effects of previous accounting choices that managers make (Barton and Simko 2002) that ultimately determine the quality of reported profits. Reflecting the properties rather than the mere level of profitability, earnings quality is a powerful surrogate of managerial bias in accounting choices (Dechow, Ge and Strand 2010, Fields Lys and Vincent 2001), and as such may contribute incremental predictive power to the book-to-market for stock returns. We, therefore, set out to explore the role of earnings quality in shaping asset prices focusing on the value-growth phenomenon.

While earnings quality has no agreed upon definition, being a highly context specific notion (Francis, Olsson and Schipper 2006, Dehow, Ge and Schrand 2010), poor earnings quality is often associated with earnings management and measured using properties of reported earnings affected by managerial discretion, e.g. earnings smoothness, earnings persistence, matching of revenues to expenses, mapping of accruals into cash flows. As a construct, earnings quality moves beyond one-off accrual estimates and adjustments to income, that may largely average out over time. Instead, earnings quality acts as a surrogate of managerial discretion/mentality in financial reporting, that is likely to be manifested in retained earnings. For example, if managers make generous assumptions about revenue recognition, these shall cumulate over time to net assets. Note, however, that while there are earnings management incentives behind accounting bias, e.g. bonus plans, debt arrangements, it is their earnings quality effects that end up cumulated in net assets and therefore may contribute to the value-growth phenomenon. In other words earnings quality becomes the surrogate of managerial accounting bias and essentially the channel through which these incentives may impact asset prices. Consistent with this notion, prior research shows that earnings quality constructs exhibit the predicted associations with earnings management incentives (Athanasakou and Olsson 2019). As a result, prior research examining 
the asset pricing implications of accounting bias focuses on measures of earnings quality. This type of research associates poor earnings quality with behavioral biases and incomplete market responses to reported profitability (e.g. Callen, Khan and Lu 2013, Hirshleifer, Lim and Teoh, 2011, Nam, Brochet and Ronen 2012, Xie 2001), as well as higher levels of systematic and idiosyncratic risk (Francis, Lafond, Olsson and Schipper 2004, 2005, Rajgopal and Venkatachalam 2011, Zhang 2010, Chen, Huang and Jha 2012). Poor earnings quality is particularly an issue of growth stocks, due to the stronger managerial incentives of growth firms to keep market expectations high and rising (Jensen 2005, Skinner and Sloan 2002). Overvalued equity, often associated with bloated balance sheets is a key trigger of further managerial discretion to maintain market expectations (Hirshleifer, Hou, Teoh and Zhang 2004, Houmes and Skantz 2010). As such, poor earnings quality, especially of growth stocks, is likely to contribute to the value-growth phenomenon.

To date, the risk or behavioral bias inducing effect of poor earnings quality has been largely examined independently of the value-growth phenomenon. The reason earnings quality has been often associated with idiosyncratic risk, behavioral biases and incomplete market responses to reported earnings, is the opaque nature of managerial discretion, which may affect the speed with which market prices respond to firm fundamentals (Callen, Khan and Lu 2013, Zhang 2006). For example, poor earnings quality may affect investors' tendency to extrapolate performance, especially of growth relevant to value stocks, yielding forward returns as the market begins to fully assess firm fundamentals (see detailed discussion in Section II). Alternatively, poor earnings quality may cause investors to disagree more about firm value exacerbating the potential dominance of optimistic investors in price setting, and leading to lower future returns. The implications of managerial discretion on asset pricing is even more important in the presence of more subtle instances of earnings management. Over recent years real earnings management, i.e., real operating and investment decisions targeted at inflating firm profitability, has gained space to the more conventional approaches of earnings management using accruals (Cohen and Zarowin 2010), raising the need to explore the implications of broader constructs of managerial discretion moving beyond accruals.

To explore the role of earnings quality in the book-to-market's predictive power of expected returns, or the value premium, we use a common factor score of three common and broad measures of earnings 
quality, i.e., earnings volatility, accruals quality and absolute abnormal accruals. Earnings volatility has been shown to be associated with several earnings properties, like earnings smoothness, earnings predictability, and poor matching of revenue to expenses. We use a common factor of all three measures as we are interested in a comprehensive measure of managerial discretion, i.e., a measure that captures multiple forms of earnings management (e.g., smoothing, income inflation, income deflation) and multiple tools (accruals based earnings management and real earnings management). Prior research affirms the comprehensive nature of such common factor by showing that it exhibits associations with earnings management incentives as predicted by the theories of accounting choice, i.e., positive association contractual incentives (e.g., executive compensation and debt arrangements), asset pricing motivations (e.g., meeting market expectations) and negative association with public visibility (Athanasakou and Olsson 2019).

We find evidence of a value premium over our sample period, primarily within stocks with poor earnings quality. We then run Fama and MacBeth (FM, 1973) regressions of one- year ahead returns against earnings quality and find evidence that value premium rises with poor earnings quality after controlling for firm size. We then proceed by examining one-year ahead returns across the value-growth and poor-good earnings quality space. One-year-ahead buy-and-hold returns, decline sharply for growth stocks but do not change significantly for value stocks as we go from the highest to the poorest earnings quality stocks, even after controlling for size. This result suggests that deteriorating earnings quality contributes to the value-growth phenomenon mainly through the pricing of poor quality growth stocks. Examining stock returns for value and growth stocks separately for three years before to three years after the portfolio formation lends further support to this conclusion. Growth (value) stocks earn high (low) returns in the three years leading up to the portfolio formation date and low (high) returns for the following four years, and this pattern is more pronounced for the poorest earnings quality stocks.

For completeness, we also carry out asset pricing tests. Using augmented Fama and French three and five-factor models, and testing 25 Book-to-Market/Earnings Quality portfolios, we find that an earnings quality factor added to the three and five-factor models is incrementally predictive. The five-factor model augmented with an earnings quality factor is the best relative representation of asset prices in our sample. 
These results suggest that the earnings quality factor predicts returns incrementally to profitability and investment factors.

Collectively, our results suggest that earnings quality contributes to the value-growth phenomenon, mainly through the pricing of poor earnings quality growth stocks. Our analysis affirms prior evidence associating the value-growth effect with factors related to risk (e.g., idiosyncratic stock volatility, absolute forecast error) and factors related to behavioral biases (e.g., poor stock visibility, low price) and shows that poor earnings quality contributes to the relevant pricing of growth stocks primarily through behavioral biases.

Our analysis contributes to three streams of literature. First, our results add to recent research highlighting the role of earnings in shaping asset prices and the value factor (Ball et al. 2019, Fama and French 2015, Novy-Marx 2013, Ball, Gerakos, Linnainmaa and Nikolaev 2016) by highlighting the role of the broader construct of earnings quality. By focusing on the properties rather than the mere level of reported earnings, the earnings quality construct is a powerful surrogate of managerial bias in accounting choices and therefore a potential channel through which behavioral biases may contribute to the value premium. As such, we use a comprehensive measure of earnings quality to capture earnings properties associated with multiple forms and tools of earnings management. Our analysis highlights the need to examine broad properties rather than the mere level of reported profits when examining how earnings shape asset prices and the value premium, and to focus on earnings related behavioral biases alongside risk related factors. Second, our results advance research examining earnings quality of value versus growth firms (Lee, Li, and Yue 2006, Desai, Rajgopal and Venkatachalan 2004) by showing the implications for the value premium. As such, our results also expand research on the asset pricing effects of earnings quality issues of growth firms (Jensen 1995, Skinner 2000) by drawing a link to the broader book-to-market factor. Finally, our results contribute to the literature that studies the drivers of the value premium (Asness Frazzini and Moskowitz 2015, Athanassakos 2011), by reaffirming both risk and behavioural biases as sources of the value premium and highlighting earnings quality as a source of behavioral biases.

Our findings have important implications for investors and financial analysts. Properties of reported earnings, ranging from the volatility of earnings to the extent that accruals are correlated with operating cash flows and the absolute value of abnormal levels of accruals, seem to 
underlie the book to market's predictive power in the cross section of stock returns. This insight is useful for any investment strategies that follow a systematic approach in determining the intrinsic value of the underlying securities, affirming the important role of identifying the effects of earnings quality (Fairfield and Whisenant 2001), alongside all remaining factors associated with risk and performance. Insofar as earnings quality effects are integral to corporate governance structures, our findings also have implications for policy makers and corporations, as governance structures may be a tool to moderate the earnings quality effects on asset prices and the value factor.

The rest of the paper is structured as follows: Section II develops the research questions and forms expectations. Section III discusses the methods, measures and data. Section IV presents the empirical results of (a) univariate and bivariate tests of the relationship of the value premium and earnings quality to risk and behavioral proxies (b) Fama and MacBeth (1973) tests and analysis, and (c) additional tests, including asset pricing tests. Finally, section V concludes the paper.

\section{Related literature and formation of expectations}

Literature on the value-growth phenomenon has shed light to two key explanations, risk and behavioral biases. A bulk of studies have associated the value premium with measures of risk, such as the standard deviation of returns, or of analyst forecasts and idiosyncratic volatility (Athanassakos 2009, Ang and Chen 2007, Vassalou and Xing 2004, Adrian and Franzoni 2005, Lewellen and Nagel 2006, Petkova and Zhang 2005, Doukas, Kim and Pantzalis 2004, Athanassakos 2011, Ackert and Athanassakos 1997, Li, Brooks and Miffre 2009, Fan, Opsal and Yu 2015, Guo, Savickas, Wang and Yang 2009, Cao 2015, Hou and Loh 2016). A parallel stream of literature associates the value premium with errors in expectations, as investors may be too optimistic for growth relative to value stocks (seminal paper, Lakonishok, et al. 1994). This stream of research offers evidence associating the value premium with poor analyst following and small firm size, and other factors associated with behavioral biases that could affect the pricing of growth versus value stocks (Phalippou 2008, Athanassakos 2011, Piotroski and So 2012, Chaves et al. 2013, Chen at al. 2015, Fisher et al. 2016 and Walkshaus1 2016).

More recent reaearch explores further the role of earnings and the 
value premium. Ball et al. (2018) focus on the role of retained earnings within the book value of equity and show that it subsumes the book to market's predictive power in the cross section of stock returns. Retained earnings reflect a firm's earnings yield, but also cumulate over the years the effects of managerial discretion impounded on reported profits (Barton and Simko, 2002) and therefore earnings quality. Earnings quality, reflected in the properties of reported profits rather than the mere level of reported earnings, is a powerful surrogate of managerial bias in accounting choices as it further reflects the effects of discretionary accounting choices on firm risk (Dechow et al. 2010). As such earnings quality should be a leading priority for accounting and market regulators who seek to protect unsophisticated investors from opportunistic managerial behavior and ensure the release of optimal accounting information (Kothari Ramanna and Skinner 2010). Earnings quality issues are also at the forefront for market participants in the presence of accounting related anomalies that evolve over time with earnings management tools (Richardson, Tuna and Wysocki, 2010).

Earnings quality has predictive power for future returns both as a risk factor and as a source of behavioral biases. On one hand, while evidence on the pricing of earnings quality may be driven largely by earnings quality's association with fundamental risk (Core, Guay and Verdi, 2008, Chen, Dhaliwal, and Trombley 2008), recent research also alludes to an association between earnings quality and idiosyncratic risk, by showing that much of the variation in stock return volatilities is driven by earnings volatility (Rajgopal and Venkatachalam 2011), especially insofar as they are associated with managerial discretion (Chen, Huang, and Jha 2012). Earnings quality issues may be a source of information risk particularly for value stocks, as prior evidence suggests such stocks are facing financial distress and poor operating performance both of which introduce noise to reported earnings (Ashbaugh et al. 2006, Bharath et al. 2008, Graham, Li and Qiu 2008, Beneish 1997). For earnings quality issues to contribute the value premium as a source of risk, they need to induce more information risk for value than growth stocks. As such, earnings quality issues of value stocks, proxying for information risk, may contribute to a risk based explanation of the value premium. In this case, we would expect the value premium to increase with deteriorating earnings quality. To the extent that deteriorating earnings quality induces higher risk for value than for growth stocks it could contribute to a risk based explanation for the value premium. 
On the other hand, earnings quality issues have also been associated with behavioral biases. Poor earnings quality, driven by earnings management, may impair the market's ability to fully assess the implications of earnings due to the unobservable and subtle nature of managerial discretion. Relevant guidance, especially with respect to accruals based earnings management, is provided indirectly by the accruals anomaly literature (Nam, Brochet and Ronen 2012, Xie 2001, Sloan 1996). This strand of research focuses on the pricing implications of highly positive (negative) accruals, which seem to be associated with predictably lower (higher) abnormal returns in the subsequent period (Sloan 1996). The accruals anomaly literature has examined the potential overlap of the value versus growth anomaly and the accruals anomaly, as both anomalies are associated with the reversal of prior period stock returns (Desai et al. 2004). The basic reason for the overlap is that growth stocks experience high growth in sales that may give rise to high positive accruals. As a result, investors' pricing of growth stocks may be due to the pricing of their positive accruals and could be the reason that growth stocks underperform value stocks in subsequent periods. ${ }^{1}$ In a similar vein, value stocks may experience negative accruals (a common characteristic of firms facing bankruptcy, financial distress, overcapacity, or decline in profitability), which may lead to positive abnormal returns in subsequent periods. This line of argument provides a potential explanation for the value premium based on the relative valuation of accruals of growth versus value stocks. Deteriorating earnings quality, either in the form excessively high (low) accruals for growth (value) stocks, may underlie the value premium.

Additionally, moving beyond the accruals anomaly, poor earnings quality issues may exacerbate behavioral biases in so far as they compound investors' tendency to extrapolate past performance into the future. For example, high earnings volatility may fuel investor optimism (pessimism) with respect to growth (value) stocks. Alternatively, high earnings volatility may cause investors to disagree about firm value, exacerbating the potential dominance of optimistic investors in price setting which leads to lower future returns (Diether, Malloy and Scherbina 2002, Ang, Hodrick, Xing and Zhang 2006, Miller 1977). This reinforces our expectation that deteriorating earnings quality, triggering behavioral biases, should be positively related to the

1. Growth stocks' susceptibility to such pricing protected by limits to arbitrage is supported by its residual variability posing limits to arbitrage (Brav, Heaton and Li 2010). 
value-growth phenomenon, especially through the pricing of growth relative to value stocks. As a result, to the extent that deteriorating earnings quality induces higher mispricing for growth than value stocks, we would expect that it could contribute to a mispricing explanation of the value premium.

\section{Methods, measures and data}

\section{A. Value-growth proxies}

Similar to Ball et al. (2019) and other studies focusing on the association between profitability and the value-growth effect, we use the book-to-market $(B / M)$ ratio to divide stocks into value and growth. We provide detailed definitions for all key variables in the appendix. Comparing to alternative proxies, such as operating cash flows to price $(\mathrm{OCF} / \mathrm{P})$ and earnings to price $(\mathrm{E} / \mathrm{P}), B / M$ is the least affected by earnings properties that are embedded in earnings quality, the key focus of our investigation. We compute the book-to-market ratio $(B / M)$ as the ratio of the fiscal year-end book value of equity to the market value of equity. We measure the market value of equity at the end of the fourth month following the end of the calendar year and book values of equity from all year-ends falling within this calendar year to ensure all the accounting variables for the previous year-end are available at the portfolio formation date. At the end of April every year firms are ranked based on $B / M$ ratios from low to high and the ranked firms are divided into five groups of equal size. Quintile-1 $(Q 1)$ is the low $B / M$ ratio quintile or the growth stocks, while Quintile-5 (Q5) is the high $B / M$ ratio quintile or the value stocks. ${ }^{2}$

\section{B. Returns}

We calculate annual buy-and-hold total returns for each firm for the year after the portfolio is formed, i.e., the twelve months starting on the fifth month after the calendar year- end (Ret 1) (Fama and French 1992, Lakonishok, Shleifer and Vishny 1994, and La Porta, Lakonishok, Shleifer and Vishny 1997). All firms in our sample have reported

2. We obtain similar results when using deciles in our analysis instead of quintiles. Results available upon request. 
financials for fiscal year $(t-1)$ by April of year $(t)$, so the starting period of the return accumulation period ensures complete dissemination of accounting information in the financial statements of the previous year. For the main part of the analysis we use individual stock return data. For asset pricing tests, we use value weighted portfolio returns.

\section{Earnings quality measure}

For our main analysis, similar to Francis, Nanda and Olsson (2008), we use a combined measure of earnings quality based on the common factor, $E Q$, identified by factor analysis performed on three common measures of earnings quality: a) earnings variability (EarnVar); b) accruals quality $(A Q)$; and c) absolute abnormal accruals $(A b s A A){ }^{3}$ The standard deviation of earnings, (i.e., earnings variability) EarnVar, has been shown to work as an instrument for various earnings quality measures, such as earnings smoothness, earnings predictability, accruals quality, poor matching of revenue and expenses, etc. (Francis et al. 2004, Dichev and Tang 2008, 2009), and is broad enough to reflect the risk of the firm's business model and the effect of managerial discretion. We calculate EarnVar as the standard deviation of firm $j$ ' earnings before extraordinary items, scaled by total assets, calculated over years $t-4$ through $t$. Higher values of EarnVar indicate higher earnings volatility. The Dechow and Dichev (2002) measure of accruals quality, $A Q$, captures the standard deviation of accrual estimation errors, working capital accruals that do not map into cash flows in the current, prior, and future periods or changes in revenues and property, plant and

3. For the absolute value of abnormal accruals, $A b s A A$, we use the modified Jones (1991) as follows:

$$
T \frac{T A_{j, t}}{\text { Assets }_{j, t}}=\beta_{1, j} \frac{1}{\text { Assets }_{j, t}}+\beta_{2, j} \frac{\Delta \operatorname{Rev}_{j, t}}{\text { Assets }_{i, t}}+\beta_{3, j} \frac{P P E_{j, t}}{\text { Assets }_{j, t}}+u_{j, t}
$$

where $T A$ is total accruals. The industry- and year-specific parameter estimates from equation (1) are used to estimate firm-specific normal accruals:

$$
N A_{j, t}=\hat{\beta}_{1} \frac{1}{\text { Asset }_{j, t}}+\hat{\beta}_{2} \frac{\Delta \operatorname{Rev}_{j, t}-\Delta A R_{j, t}}{\text { Assets }_{i, t}}+\hat{\beta}_{3, j} \frac{P P E_{j, t}}{\text { Asset }_{j, t}}
$$

where $\triangle A R$ is change in accounts receivable and abnormal accruals $(A A)$ in year $t, A A_{j, t}=T A_{j, t}$ IAsets $_{j, t-1}-N A_{j, t}$. 
equipment. ${ }^{4}$ Similar to earnings volatility, $A Q$ has been shown to work as an instrument for several earnings quality measures like earnings persistence, poor matching of revenues to expenses, and the total magnitude of accruals. $A Q$ has also been explicitly portrayed as including both unintentional estimation errors due to business volatility, and intended to also capture intentional errors driven by managerial discretion.

The resulting common factor, $E Q$, has the same ordering as the underlying variables, so larger values of $E Q$ indicate higher earnings volatility and higher volatility and latitude of accrual estimation errors, therefore higher accounting discretion and poorer earnings quality.

The use of a common factor of earnings quality is in line with our objective to use a comprehensive measure of managerial discretion. The factor score has two distinct benefits over individual measures. First, the common factor captures multiple aspects of managerial discretion, and therefore forms of earnings management, that a single measure may be unable to incorporate. For example, earnings volatility is likely to capture income smoothing attempts across periods, whereas absolute abnormal accruals may offer a more accurate measure of income inflation attempts. Second, the common factor embraces different tools of managerial discretion.

4. The Dechow and Dichev (2002) model, as extended by McNichols (2002), measures the extent to which working capital accruals map into cash flows in the current, prior, and future periods and changes in revenues and property, plant and equipment as follows:

$$
\begin{aligned}
\frac{\text { CCA }_{j, t}}{\text { Assets }_{j, t}}= & a_{0, j}+a_{1, j} \frac{C F O_{j, t-1}}{\operatorname{Assets}_{j, t}}+a_{2, j} \frac{C F O_{j, t}}{\operatorname{Assets}_{i, t}}+a_{3, j} \frac{C F O_{j, t+1}}{\operatorname{Assets}_{i, t}} \\
& +a_{4, j} \frac{\Delta \operatorname{Rev}_{j, t}}{\operatorname{Assets}_{j, t}}+a_{5, j} \frac{P P E_{j, t}}{\operatorname{Assets}_{j, t}}+v_{j, t}
\end{aligned}
$$

where TCA is total current accruals, Assets is average total assets in year $t$ and $t-1, C F O$ is cash flows from operations, NIBE is net income before extraordinary items, $\triangle R E V$ is change in revenues, and $P P E$ is the gross value of property, plant and equipment. Exact definitions for all variables are listed in the appendix. We estimate equation (3) for each of Fama and French's (1997) 48 industry groups with at least 20 firms in each industry-year combination. Annual cross-sectional estimations of (3) yield firm- and year-specific residuals, which form the basis for the accruals quality metrics: $A Q_{j, t}=\sigma\left(v_{j}\right)_{t}$ is the standard deviation of firm $j$ 's residuals, $v_{j, t}$, calculated over years $t-4$ through $t$. Larger values of $A Q$ indicate higher volatility of accrual estimation errors. Because of the lead term in equation (3) we lag the measure one year to ensure we are not conditioning on future information. 
For example, accruals quality and abnormal accruals measure accruals based earnings management, whereas earnings volatility is able to also reflect the effects of real earnings management attempts. These two benefits are important for our research perspective, i.e., our viewing earnings quality as a surrogate of managerial discretion. Initial analysis (not tabulated) shows that $E Q$ is highly correlated with all three measures of earnings quality ( $50 \%$ or higher) as in Francis et al. (2008), indicating that these measures contribute non-trivially to the common factor. Correlations are also high (ranging from $26 \%$ to $54 \%$ ) among the three measures of earnings quality, EarnVar, $A Q$, and $A b s A A$, which is consistent with our measures capturing common features of earnings quality in non-overlapping dimensions, in line with our objective. As a robustness test we repeat our analysis using EarnVar, as it has been shown to be the most comprehensive measure (associated with earnings smoothness, earnings predictability, accruals quality, poor matching of revenue and expenses). Though the results are somewhat weaker, in line with our argument, we retain our key inferences. ${ }^{5}$

For some tests we also use quintiles of the variable $E Q$, pretty much like the quintiles based on $B / M$. At the end of April every year firms are

5. While prior literature offers ways to detect firms that are likely manipulating operating activities (real earnings management, REM) (e.g. Roychowdhury 2006, Gunny 2010), the earnings quality literature has yet to explicitly assess the earnings quality effects of REM. Roychowdhury (2006) examines REM using abnormal levels of operating cash flows $(A C F O)$, production costs $(A P R O D)$ and abnormal levels of selling general and administrative expense $(A S G \& A)$. Abnormally low operating cash flows are associated with attempts to accelerate revenues using price discounts or more lenient credit terms. Abnormally high production costs are associated with attempts to overproduce, so that fixed production costs remain lodged in inventory and profits increase. Abnormally low $S G \& A$ expenses are associated with attempts to inflate profitability by cutting discretionary spending. Collectively, REM impacts the properties of reported earnings by lowering the mapping of earnings to contemporaneous and future cash flows, i.e., firms report lower levels of cash for the same level of profits. This deterioration of matching between reported revenue and expenses is captured by both earnings volatility (EarnVar) and $A Q$ (Dichev and Tang 2008, 2009, Dechow and Dichev 2002). As a result, our main analysis is based on $E Q$ to remain close to our objective and be able to incrementally contribute to prior asset pricing studies on earnings quality. However, in additional analysis, we do calculate the REM measures proposed by Roychowdhury (2006). We estimate identifiers for firms with low operating cash flows ( $\angle C F O$ ), in the bottom quintile of $A C F O$, with high production costs $(H P R O D)$, in the top quintile of $A P R O D$, with low $\mathrm{S} \& \mathrm{~A}(L S G \& A)$, in the bottom quintile of $A S G \& A$ and then we derive an $R E M$ composite score for the sum of these identifiers in the firm-year level. Initial analysis shows that $E Q$ is $25 \%$ correlated with $R E M$ affirming that $E Q$ reflects substantial variation in $R E M$ activity. We also repeat our core tests using $E Q \_R E M$ instead of $E Q$ i.e., an earnings quality common factor that includes $R E M$, and our core inferences remain. Results are available by the authors upon request. 
ranked based on $E Q$ from low to high and the ranked firms are divided into five groups of equal size. Quintile-1 $(Q 1)$ is the low $E Q$ quintile or the good quality stocks, while Quintile-5 $(Q 5)$ is the high $E Q$ quintile or the poor quality stocks.

\section{Risk and behavioral factors}

To probe the channel through which earnings quality contributes to the value premium, we measure factors associated with risk and behavioral factors drawing from prior research.

With respect to risk factors, we consider two measures associated with analyst uncertainty, as well as a measure of idiosyncratic volatility $(\mathrm{IVol})$. Prior research offers evidence of a positive association between the value premium and these risk measures. The first measure of analyst uncertainty employed is analyst forecast dispersion, ADispersion, calculated as the standard deviation of individual analyst earnings forecasts issued during the fiscal year, divided by end of previous year stock price. ${ }^{6}$ The dispersion of analysts' forecasts represents an indication of the heterogeneity of beliefs among analysts due to the uncertainty surrounding a company's future, as discussed in Ackert and Athanassakos (1997). ${ }^{7}$ The second measure of analyst uncertainty used is the absolute value of the forecast error, |Forecast error|, calculated as the absolute value of the difference between actual EPS and the first analyst consensus forecast for the period divided by end of previous year stock price. |Forecast error| also proxies for the level of uncertainty associated with the information and environment in which

6. The standardization renders our dispersion measure scale free across firms for the cross sectional analysis conducted in each month. We opt for dividing by price rather than earnings per share as the latter may produce many outliers (Ackert and Athanassakos 1997, Cheong and Thomas 2011). Our approach is not subject to some of Cheong and Thomas' (2011) criticisms of scaling by price as in our empirical part of the study we employ $\log B M$, there are small correlations between $\log B M$ and the scaled by price variables, and finally, we do not run regressions of $\log B M$ against the scaled variables. We obtain similar results when considering the standard deviation of one-year-ahead analyst forecasts as in Doukas, et al. (2004), or the standard deviation of analyst forecasts outstanding at the beginning of the fiscal year.

7. The standard deviation of analysts' forecasts may be a better measure of risk than the standard deviation of stock returns, as it is forward looking whereas the standard deviation of stock returns is based on historical data. Other researchers, such as Doukas et al. (2004), Malkiel (1982), Williams (1977), have also shown that the dispersion in analysts' earnings forecasts represents a better measure of risk. 
a company operates. Analyst uncertainty, reflected either in higher dispersion of analyst forecasts or higher absolute forecast errors, is likely to increase the perception of investment risk and consequently the required rate of return. ${ }^{8}$ Consistent with prior research (i.e., Fan, Opsal and Yu 2015, Guo, Savickas, Wang and Yang 2009, Lewellen and Nagel 2006), we measure idiosyncratic volatility ( $I V o l)$ using the standard deviation of daily abnormal stock returns during the fiscal year. We obtain abnormal returns as the residuals from regressing the company's daily stock returns adjusted for the risk free rate on the market premium.

In terms of behavioral biases, prior research offers evidence of a positive association between the value premium and measures associated with the obscure nature of stocks. Institutional investors tend to avoid stocks that are obscure and not followed by analysts. Moreover, institutional managers have higher accountability for their portfolio choices when few analysts follow the stock; there are many risks to which institutional managers are exposed to by investing in obscure stocks or stocks that no (or only few) analysts cover. Institutional disinvestment from or avoidance of such stocks is likely to affect the speed with which stock prices respond to the stocks' fundamentals yielding higher forward returns. A common measure of obscurity is low levels of analyst coverage by financial analysts. We measure Analyst Coverage using the number of analysts following the firm each year.

Kothari, Shanken and Sloan (1995) and Loughran (1997) show that the value premium is stronger for small cap stocks. Many institutional investors constrained either by their mandate or by the fact that they have too much money to manage and small cap stocks cannot absorb enough flow, tend to avoid such stocks (Greenwald et al. 2001). As smaller companies evolve to bigger companies through growth, they may become eligible for purchase by more mutual/pension fund companies and their shares are bid up. Moreover, smaller cap companies tend to be followed by fewer analysts and owned by a smaller number of institutions, and therefore tend to be more obscure and less in the public eye than larger companies (Ackert and

8. We note that analyst forecast dispersion, as a proxy for the heterogeneous beliefs among analysts, has also been associated with behavioral factors (Diether, Malloy and Scherbina 2002, Ang, Hodrick, Xing and Zhang 2006, Miller 1977). As such, we conduct additional analysis free from the need to classify variables as proxying risk or behavioral biases. 
Athanassakos 2003). Poor stock visibility has been shown to be associated low stock returns (Hu, Dong, Liu and Yao 2013). As a result as a second measure of obscurity in stocks we consider a firm's market capitalization, $\log$ (MarketCap). We calculate market capitalization by multiplying shares outstanding by price per share at the end of the fourth month following the firm's calendar year-end. We also use stock price as a way of focusing on poor visibility stocks. Institutional investors tend to avoid low priced stocks (Falkenstein, 1996, Gompers and Metrick, 2001, Kumar and Lee, 2006). Moreover, low priced stocks are difficult to arbitrage, making stock price a good proxy for a slower speed of price discovery. ${ }^{9}$ The stock price used is as at the end of the fourth month following the calendar year-end.

\section{E. Data and sample selection}

We use U.S. stock market return data for non-financial firms from CRSP (monthly and daily stock prices, returns, and shares outstanding for AMEX, NASDAQ, and NYSE stocks). We calculate market capitalization data from this database. We use accounting data from COMPUSTAT and analyst data from Institutional Brokers Estimate System (I/B/E/S). Our sample period covers 1982-2015.

The firms included in the final sample passed through several filters. First, the share price exceeds $\$ 1$. Second, the $B / M$ ratio is positive. Third, companies have matching stock return data on CRSP available for the current and subsequent accounting period (i.e., the year following the determination of value-growth classification), and fourth, there are available data for our earnings quality common factor score. The first criterion ensures that the sample is not dominated by penny stocks as severe liquidity problems exist in this group of stocks, and extremely high stock returns are not unusual for such stocks biasing value and growth stock returns. Moreover, since the stock price is used as a scalar, excluding penny stocks prevents ratios to stock price from reaching extreme values. The second criterion prevents problems resulting from the inclusion of companies with negative $B / M$ ratios which will distort our value and growth proxies (Desai et al. 2004,

9. As Barberis and Thaler (2002), D'Avolio (2003) explain, it is possible that arbitrage may only partially adjust prices down to their appropriate level because of several impediments in arbitrage, in light of the severity of the behavioral/institutional factors. 
Lakonishok et al. 1994), and deals with potential data errors (La Porta et al. 1997, Cohen, Polk and Vuolteenaho 2003). The final sample consists of a total of 60,834 firm-year observations for 6,718 unique firms with available data for subsequent stock returns and all three measures of earnings quality. The sample with data available for all risk and behavioral factors includes 36,016 firm-year observations for 4,521 unique firms.

\section{Empirical results}

\section{A. Descriptive statistics}

Table 1 reports mean returns and other key measures across quintiles of $B / M$. It also reports $t$-tests for the difference in means between value stocks (fifth quintile of $B / M$ ) and growth stocks (first quintile of $B / M$ ). Table 1 shows that indeed there is a value premium in our sample with a mean of 0.060 ( $t$-test: 8.73 ).

We find that value stocks have higher analyst forecast dispersion than growth stocks (mean difference: 0.014 , $t$-test: 28.90), higher absolute forecast error (mean difference: $0.034, t$-test: 27.16 ) and higher IVol (mean difference: 0.001, $t$-test: 5.50). At the same time, value stocks are followed by fewer analysts (mean difference: $-7.347, t$-test: -46.29), have smaller market cap (mean difference: -2.009 , $t$-test: -78.94) and lower stock price (mean difference: $-16.551, t$-test: -58.06). The difference in the common measure of earnings quality, $(E Q)$, shows that $E Q$ of value stocks is well below the $E Q$ of growth stocks (mean difference: -0.220 , $t$-test: -26.78 ). Moreover, $E Q(Q)$, based on the quintiles by year of the $E Q$ common factor, also indicates that value stocks have higher earnings quality (lower EQ $(Q)$ ) than growth stocks (mean difference -0.284 , $t$-test: -15.77 ).

In summary, consistent with prior research findings in table $1 \mathrm{affirm}$ evidence of a value premium which is associated with higher analyst forecast dispersion and absolute forecast error, and lower visibility (analyst coverage, firm size, and price) of value stocks than growth stocks. Finally, consistent with previous research, we also find that growth stocks tend to have poorer earnings quality than value stocks (Lee, Li, and Yue 2006). We explore these findings further below. 
Earnings Quality and Book-to-Market in the Cross Section of Expected Returns 185

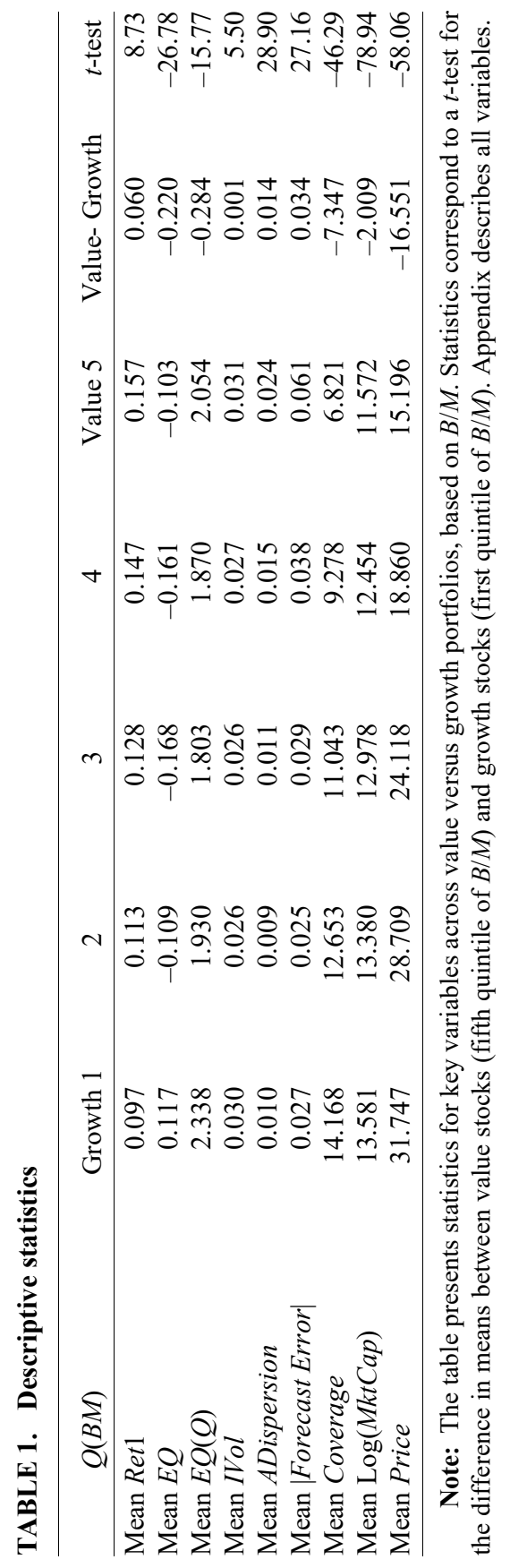


B. Earnings quality and common measures shown to be associated with the value premium

Table 2 shows how earnings quality varies with common measures that prior literature has shown to be associated with the value premium. Panel A, reports idiosyncratic volatility, $\mathrm{IVol}$, of value and growth stocks across different earnings quality quintiles. Value stocks have statistically higher mean $\mathrm{IVol}$ than growth stocks and the relationship exists across all earnings quality quintiles, except for the poorest earnings quality quintile. For example, the mean $\mathrm{IVol}$ of the highest earnings quality value firms is 0.021 , while the corresponding figure for growth firms is 0.017 ; the values for poorest earnings quality firms are 0.041 and 0.043 , respectively. Taken together, the results suggest value stocks have more idiosyncratic volatility than growth stocks, yet poor earnings quality contributes more to higher volatility for growth than for value stocks. Table 2, Panel B, reports the standard deviation of analysts' forecasts (i.e., dispersion of analyst forecasts) for value and growth stocks across different earnings quality quintiles. Value stocks have higher analyst forecast dispersion than growth stocks and this relationship is consistent across all earnings quality quintiles. The results suggest value stocks have higher analyst forecast dispersion than growth stocks and poor earnings quality contributes to a higher analyst forecast dispersion especially more for value than growth stocks. A similar picture emerges in Panel $\mathrm{C}$, which reports absolute analyst forecast error as a measure of risk for value and growth stocks across different earnings quality quintiles. We observe that value stocks have higher absolute forecast error than growth stocks and that poor earnings quality stocks have higher absolute forecast error than good earnings quality stocks. Value stocks have higher absolute forecast error than growth stocks and poor earnings quality contributes to a higher forecast error especially for value compared to growth stocks.

Table 2, Panel D, reports analyst coverage for value and growth stocks across different earnings quality quintiles. We observe that value stocks have a lower analyst coverage (i.e., visibility) than growth stocks. This is consistent across all earnings quality quintiles. For example, the highest quality value stocks have an analyst coverage of $7.815 \mathrm{vs} 18.889$ for growth stocks, while the corresponding numbers for the poorest earnings quality firms are 4.850 vs 8.914 , respectively. In addition, the lower the earnings quality, the lower the visibility across the value-growth quintiles, but the decline in visibility, as we go towards 
Earnings Quality and Book-to-Market in the Cross Section of Expected Returns 187

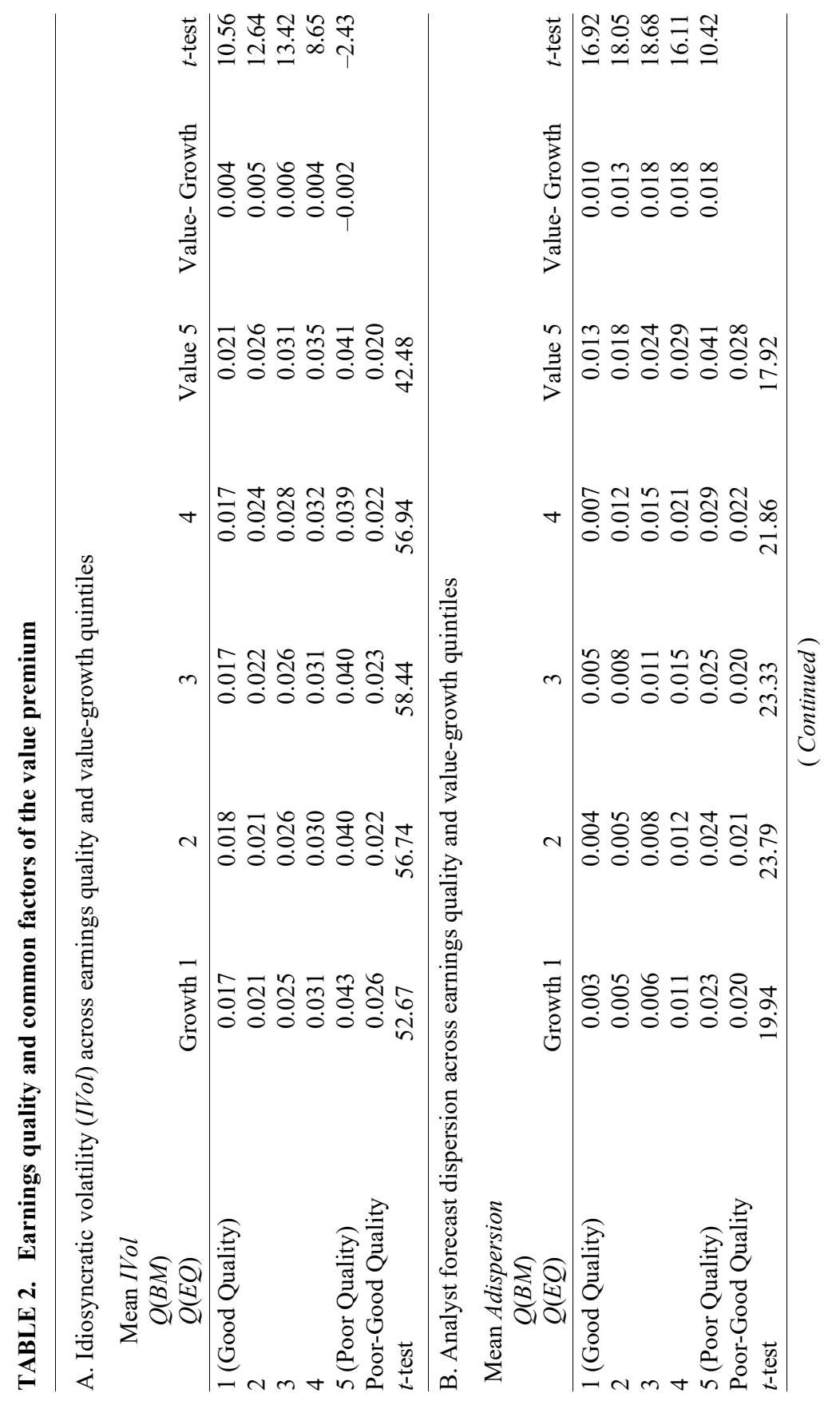




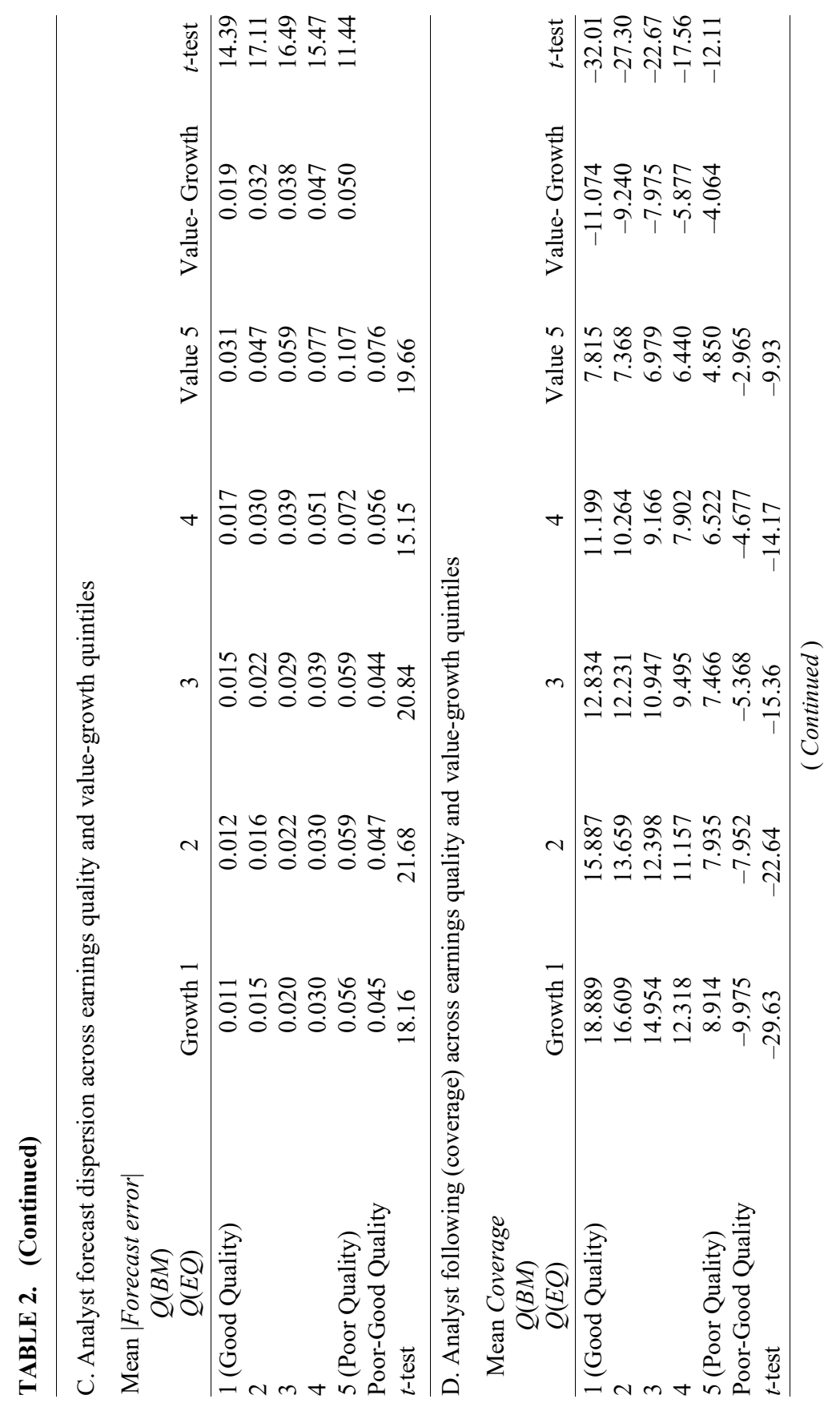


Earnings Quality and Book-to-Market in the Cross Section of Expected Returns 18

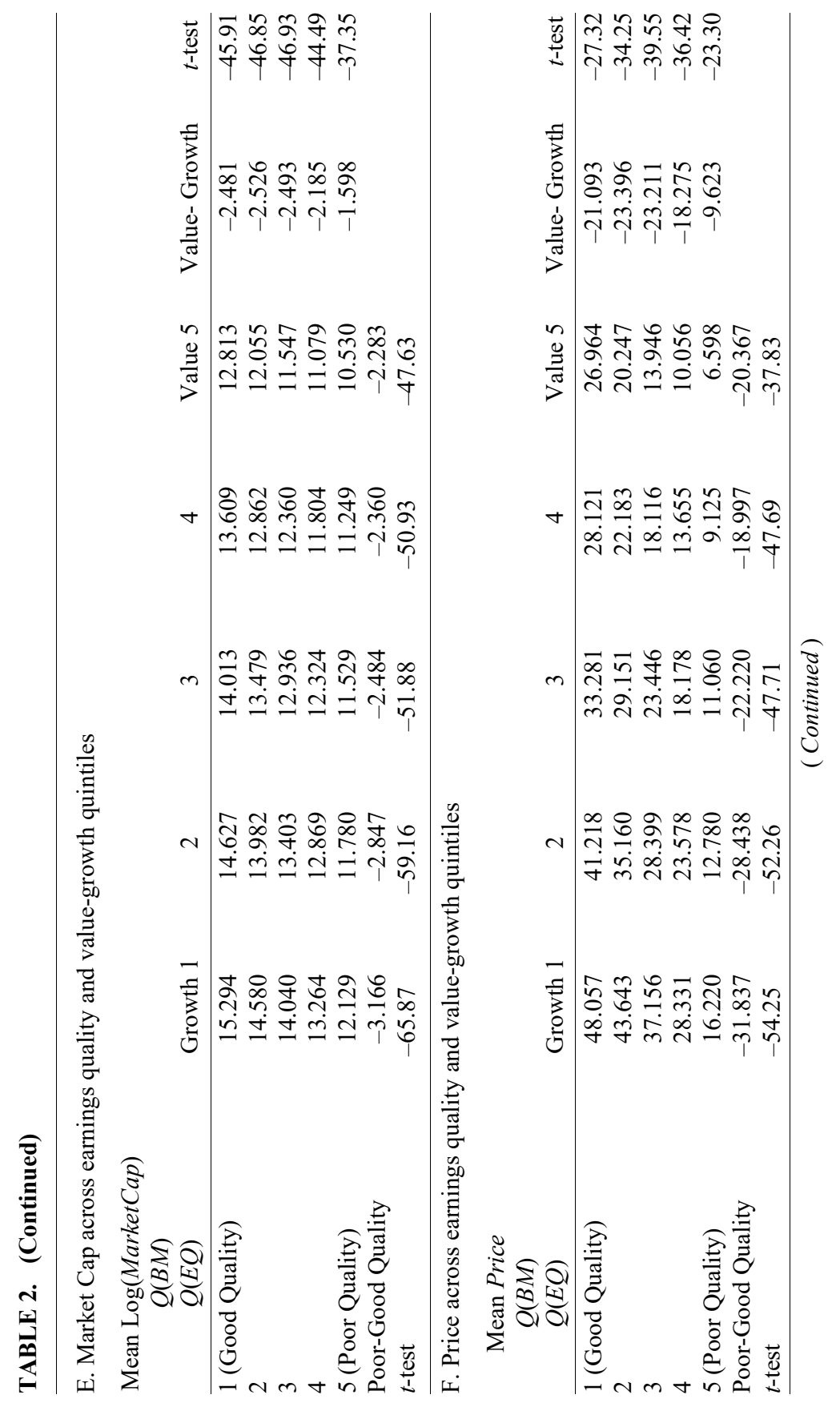




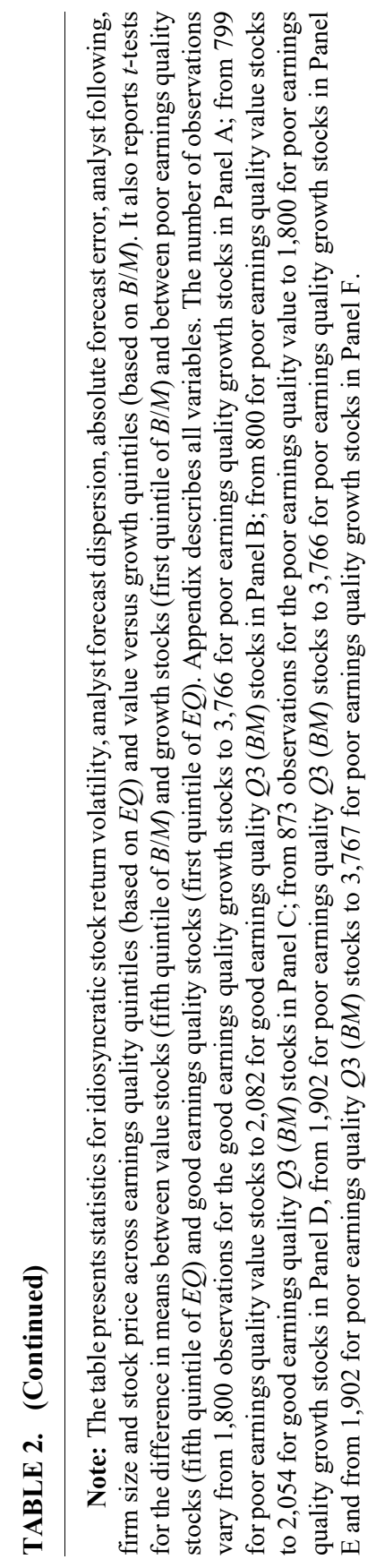


lower earnings quality quintiles, is more pronounced for growth than value stocks ( 18.889 vs 8.914 for growth stocks as opposed to $7.815 \mathrm{vs}$ 4.850 for value stocks). These results suggest that value stocks have lower analyst coverage than growth stocks, and poor earnings quality is also associated with low analyst coverage especially for growth compared to value stocks. Table 2, Panel E, reports the log market capitalization ( $\operatorname{LogMktCap}$ ) for value and growth stocks across different earnings quality quintiles. Value stocks have a lower LogMktCap (i.e., visibility) than growth stocks. In addition, the lower the earnings quality the lower the market cap across the value-growth quintiles, but the decline in market capitalization, as we go towards the lower earnings quality quintiles, is more pronounced for growth than value stocks. These results suggest that value stocks are less visible in terms of market capitalization than growth stocks, and poor earnings quality coincides with lower visibility especially for growth compared to value stocks. A similar picture emerges in table 3, Panel F, which reports the stock price for value and growth stocks across different earnings quality quintiles. We observe that value stocks have a lower price than growth stocks. In addition, the lower the earnings quality, the lower the price across the value- growth quintiles, but the decline in price, as we go towards the lower earnings quality quintiles, is more pronounced for growth than value stocks. These results suggest that value stocks are more low priced than growth stocks, and poor earnings quality coincides with lower priced stocks especially for growth compared to value stocks.

Taken together, the results of table 2 affirm prior evidence associating the value premium with higher idiosyncratic volatility and analyst forecast uncertainty and higher stock obscurity (i.e., lower coverage, small market capitalization and low stock price). They also add evidence of similar associations for poor earnings quality, with poor earnings quality contributing more to idiosyncratic volatility and obscurity of growth stocks, and to more analyst forecast uncertainty for value stocks.

\section{Value premium and Earnings quality: Fama and MacBeth Regression Analysis}

Table 3 reports Fama and MacBeth (1973) regression results of one year ahead returns against firm characteristics. In the first column, we consider firm size (LogMktCap) and $B / M(\log B M)$. Returns are 
TABLE 3. One year ahead returns, book to market and earnings quality in Fama-MacBeth regressions

\begin{tabular}{lccccc}
\hline & $\begin{array}{c}\text { Ret } 1 \\
\text { Variables }\end{array}$ & $\begin{array}{c}\text { Ret } 1 \\
\text { Coef./(t-stat) }\end{array}$ & $\begin{array}{c}\text { Ret } 1 \\
\text { Coef./ }(t \text {-stat })\end{array}$ & $\begin{array}{c}\text { Ret } 1 \text { Growth. }(t \text {-stat }) \\
\text { Coef./ }(t \text {-stat })\end{array}$ & $\begin{array}{c}\text { Ret } 1 \text { Value } \\
\text { Coef./ }(t \text {-stat })\end{array}$ \\
\hline Intercept & $0.239^{* *}$ & $0.285^{* * *}$ & $0.210^{* *}$ & 0.090 & $0.263^{* * *}$ \\
& $(2.30)$ & $(2.90)$ & $(2.66)$ & $(0.81)$ & $(3.29)$ \\
$\log ($ MktCap $)$ & 0.002 & -0.003 & -0.002 & 0.007 & $-0.010^{*}$ \\
& $(0.36)$ & $(-0.65)$ & $(-0.53)$ & $(1.17)$ & $(-1.85)$ \\
$\log (B M)$ & $0.018^{* *}$ & $0.012^{*}$ & 0.003 & 0.004 & -0.007 \\
& $(2.30)$ & $(1.77)$ & $(0.58)$ & $(0.66)$ & $(-0.75)$ \\
$E Q(Q)$ & & $-0.013^{* *}$ & $-0.021^{* * *}$ & $-0.019^{* *}$ & $-0.014^{* *}$ \\
$\log (B M) \times E Q(Q)$ & $(-2.19)$ & $(-3.11)$ & $(-2.67)$ & $(-2.06)$ \\
$N$ & & $0.005^{* *}$ & & \\
Avg. R-square & 0.0049 & 0.0054 & 0.0041 & 0.0052 & 0.0012 \\
\hline
\end{tabular}

Note: The table presents average Fama and MacBeth (1973) regression slopes and their $t$-values from cross sectional regressions of one year ahead buy-and-hold returns (accumulation starting on the fifth month after the fiscal year-end) on a number of explanatory variables. ${ }^{* *},{ }^{* * *}$ stand for significance at the $5 \%$ and $1 \%$ level, respectively. T-statistics are adjusted using the Newey-West procedure and account for heteroscedasticity and autocorrelations. Appendix describes all variables.

positively related to $\log B M$ (coeff: $0.018, t=2.30$ ), consistent with the existence of a value premium, which is robust to controlling for firm size. In the next column, we add quintiles of earnings quality, i.e., $E Q(Q) \cdot{ }^{10}$ We document a negative loading on $E Q(Q)$ (coeff: $-0.013, t$ $=-2.19)$, consistent with poor earnings quality stocks underperforming to good earnings quality stocks. ${ }^{11}$ In the third column, we add an interaction term of $\log B M$ and quintiles of $E Q(Q)$ and find that it loads positively (coeff: $0.005, t=2.50$ ). This result supports our proposition that earnings quality contributes to the value premium. In the final two columns, we repeat the analysis for value and growth stocks separately. $E Q(Q)$ loads negatively on both value and growth stocks, but it has a statistically stronger negative loading for growth (coeff: -0.019$)$ than

10. We use $E Q(Q)$ here to make results comparable with Chichernea et al. (2012).

11. This is consistent with the negative return differential moving from good to poor earnings quality that we show later on in table 5 and the overall decline in returns of poor earnings quality stocks, either growth or value, over the three years following the portfolio formation compared to the three years preceding the portfolio formation date that we will show in table 6. 
TABLE 4. One year ahead returns, risk and behavioral biases factors and book-to-market in Fama-MacBeth regressions

\begin{tabular}{|c|c|c|c|}
\hline & $\begin{array}{l}\qquad \text { Ret } 1 \\
\text { Entire Sample } \\
\text { Coef./(t-stat) }\end{array}$ & 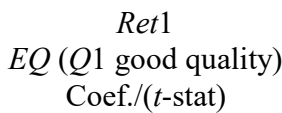 & $\begin{array}{c}\operatorname{Ret} 1 \\
E Q(Q 5 \text { poor quality }) \\
\text { Coef./( } t \text {-stat })\end{array}$ \\
\hline Intercept & $\begin{array}{l}0.513 * * * \\
(2.56)\end{array}$ & $\begin{array}{l}0.375^{* *} \\
(2.09)\end{array}$ & $\begin{array}{l}1.107 * * \\
(2.54)\end{array}$ \\
\hline $\log (M k t C a p)$ & $\begin{array}{l}-0.024 \\
(-1.52)\end{array}$ & $\begin{array}{l}-0.018 \\
(-1.46)\end{array}$ & $\begin{array}{l}-0.078^{* *} \\
(-2.51)\end{array}$ \\
\hline $\log (B M)$ & $\begin{array}{c}0.009 \\
(1.06)\end{array}$ & $\begin{array}{c}0.002 \\
(0.37)\end{array}$ & $\begin{array}{c}-0.004 \\
(-0.32)\end{array}$ \\
\hline$C F($ Risk $) \times \log (B M)$ & $\begin{array}{l}0.011^{* *} \\
(2.22)\end{array}$ & $\begin{array}{l}0.037 * * \\
(2.05)\end{array}$ & $\begin{array}{l}0.011^{*} \\
(1.86)\end{array}$ \\
\hline$C F($ Behavioral $) \times \log (B M)$ & 1) $\begin{array}{l}0.007^{*} \\
(1.69)\end{array}$ & $\begin{array}{r}0.001 \\
(0.08)\end{array}$ & $\begin{array}{l}0.021^{* *} \\
(2.67)\end{array}$ \\
\hline$C F($ Risk $)$ & $\begin{array}{r}0.067 \\
(1.58)\end{array}$ & $\begin{array}{l}0.225^{*} \\
(1.81)\end{array}$ & $\begin{array}{r}0.062 \\
(1.28)\end{array}$ \\
\hline$C F($ Behavioral $)$ & $\begin{array}{c}0.015 \\
(0.28)\end{array}$ & $\begin{array}{l}-0.010 \\
(-0.19)\end{array}$ & $\begin{array}{c}0.026 \\
(0.23)\end{array}$ \\
\hline Avg. R-square & 0.006 & 0.002 & 0.004 \\
\hline
\end{tabular}

Note: The table presents average Fama and MacBeth(1973) regression slopes and their $t$-values from cross sectional regressions of one year ahead buy-and-hold returns (accumulation starting on the fifth month after the fiscal year-end) on a number of explanatory variables. $C F$ (Risk) and $C F($ Behavioral) are common risk and mispricing scores based on factor analysis of the paper's risk (i.e., $I \mathrm{Vol}$, analyst forecast dispersion and forecast error) and behavioral variables (i.e., analyst coverage, market capitalization and stock price). $*, * *, * * *$ stand for significance at the $10 \%, 5 \%$ and $1 \%$ level, respectively. T-statistics are adjusted using the Newey-West procedure and account for heteroscedasticity and autocorrelations. The number of observations is 60,834 . Appendix describes all variables.

value stocks (coeff: -0.014$)$. This implies that growth stock returns fall more sharply than value stock returns as $E Q(Q)$ rises. Taken together the findings in table 3 affirm the important role of earnings quality in determining value and growth stock returns, after controlling for firm size, and at the same time suggest that earnings quality contributes to the value premium mainly through the pricing of growth stocks.

To shed further light on the effect of firm characteristics on value and growth stock returns, we run Fama and MacBeth regressions of one year ahead returns on $\log M k t C a p$, and $\log B M$ (as in Ball et al. 2019), adding two composite factors, one common factor of idiosyncratic volatility, analyst forecast dispersion and absolute forecast error, $C F($ Risk) and a second common factor of poor analyst coverage, small market capitalization and low priced stock $C F$ (Behavioral), and their 
interactions with LogMktCap and $\log B M$. Table 4 reports the regression results. In the first column, the key variables are the two interaction terms. Both $\log B M * C F($ Risk) and $\log B M *$ $C F$ (Behavioral) have positive loadings (namely, coeff: $0.011, t=2.22$ and coeff: $0.007, t=1.69$, respectively). These results suggest that the value premium increases with factors associated with both higher risk and higher obscurity. In the next two columns, we repeat the analysis separating the best earnings quality stocks (the lowest $E Q$ quintile) from the poorest earnings quality stocks (the highest $E Q$ quintile). $\log B M^{*}$ $C F($ Risk) remains positive and significant for both types of stocks (good and poor earnings quality), yet substantially lower for stocks with poor earnings quality (namely, coeff: $=0.037, t=2.05$ and coeff: $=0.011$, $t=1.86$, respectively). $\log B M * C F$ (Behavioral) is positive and significant only for firms with the poorest earnings quality (coeff: $=0.021, t=2.67$ ). Taken together the results of table 4 affirm evidence of prior literature associating the value premium with factors associated with risk and behavioral biases, adding a key insight that poor earnings quality contributes to the value premium mainly through behavioral factors, i.e., more obscure growth stocks. ${ }^{12}$

\section{Value premium and earnings quality: a closer lens}

Shedding further light into our multivariate results, table 5, Panel A, reports one year ahead buy-and-hold returns, Ret 1 , for value and growth stocks across different earnings quality quintiles. A number of interesting results emerge.

First, we observe that while a value premium is evident in the total sample, the value premium appears to be driven primarily by firms in poorer earnings quality quintiles. The mean value premium for the best earnings quality firms is 0.009 and not statistically significant, whereas the corresponding value premium for the poorest earnings quality firms is 0.100 ( $t$-test: 5.88$)$.

Second, the value premium increases from high to low earnings quality quintiles. This is due to the sharply decreasing mean one-year

12. R-squares tend to be quite small in all regressions in this section. However, as Neter and Wasserman (1974) explain, low R-square does not present a problem as long as the coefficients of the explanatory variables are significant. The regression coefficients is what matters as they estimate the magnitude of the effect of the relationship between dependent and independent variables. 
ahead returns for growth stocks and correspondingly flat mean returns for value stocks. The Ret 1 differential between highest and poorest earnings quality firms is -0.102 for growth stocks, as mean returns of growth stocks decline from 0.142 for the best earnings quality firms to 0.040 for the poorest earnings quality firms, but only -0.011 and not statistically significant for value stocks, as one year ahead mean returns are 0.151 for the best earnings quality firms and 0.140 for the poorest earnings quality firms.

To mitigate concerns over the effect of firm size on the above findings, given its inherent association with earnings quality (Dechow and Dichev 2002), we repeat the analysis using an earnings quality common factor that is orthogonal to total assets. We derive this measure by regressing $E Q$ on total assets and retaining the regression residuals. Table 5, Panel B reports the results of double sorting in value and growth stocks quintiles and good earnings vs poor earnings quintiles based on the orthogonal $E Q$. We obtain qualitatively similar results to Panel A. The size of the value premium rises with deteriorating earnings quality and this seems to be driven primarily by the decline in one-year ahead returns of growth stocks. However, as expected, the value premium difference between the good and poor earnings quality quintiles in Panel B is narrower and more statistically significant than in Panel A.

Overall, the results in table 5 affirm the positive relationship between the value premium and the $E Q$ metric and are consistent with earlier evidence that poor earnings quality contributes to the value premium. Moreover, it seems that the premium is led by the lower oneyear ahead returns of poor earnings quality growth stocks. ${ }^{13}$ For value stocks, there is no evidence that poor earnings quality exerts a discernible effect. Table 5, therefore, affirms findings thus far that poor earnings quality contributes to the value premium mainly through the pricing of poor earnings quality growth stocks.

13. A potential explanation is that as growth stocks, on average, tend to be bid up by investors, the less visible ones are bid up the most (Lakonishok, Shleifer and Vishny 1994, Phalippou, 2008) and as poor earnings quality growth stocks are much less visible than good quality growth stocks (table 2, Panel D) and hence are bid up the most, they end up having lower returns going forward than the better quality growth stocks. 

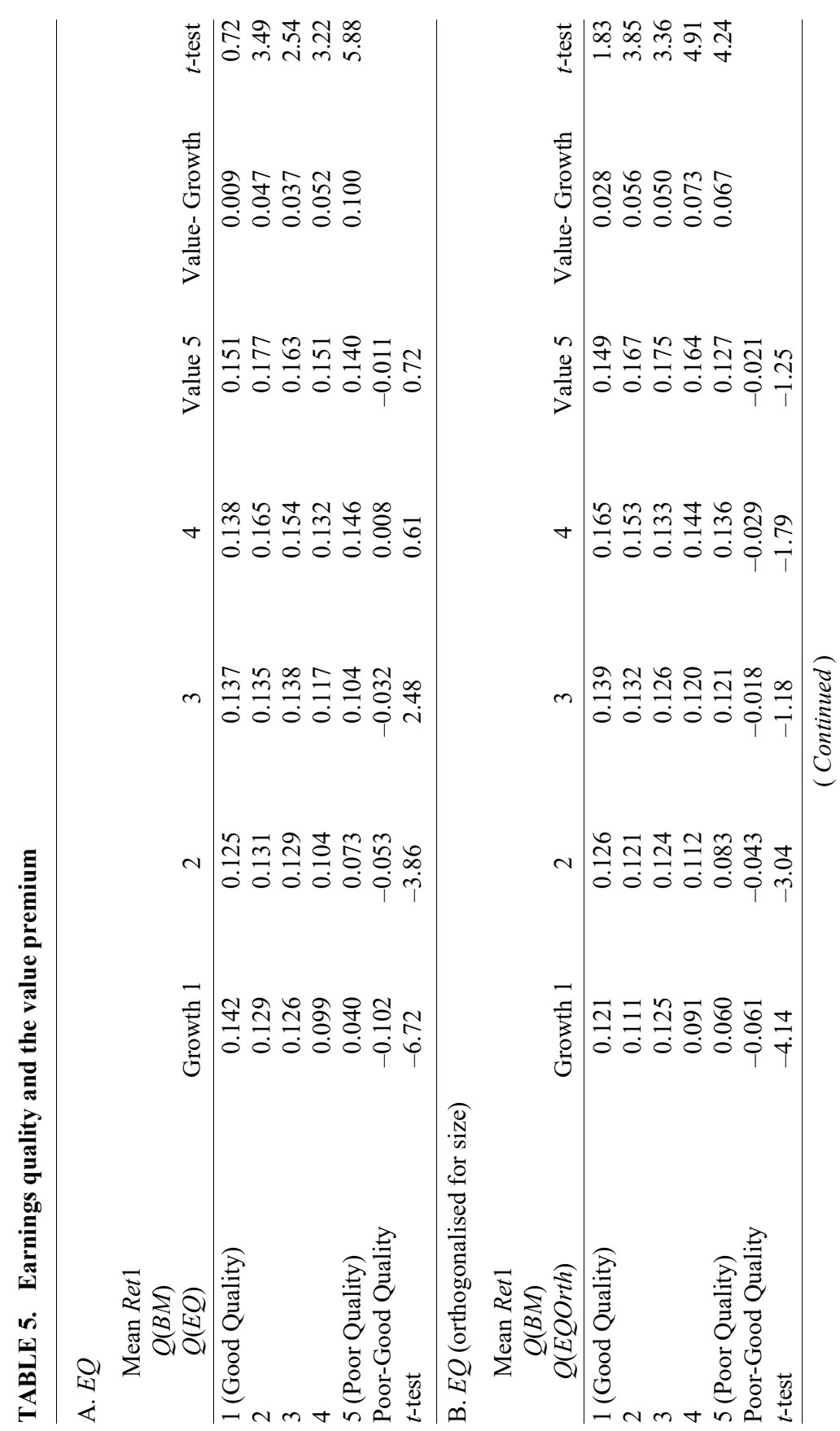


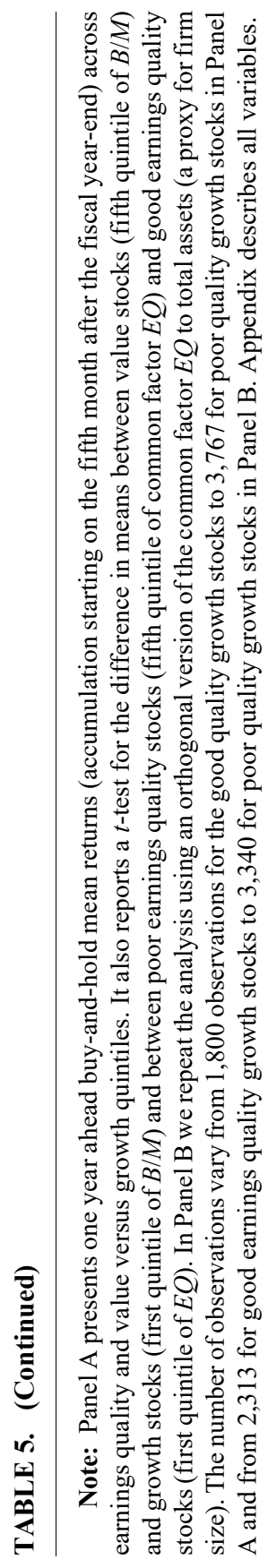




\section{E. Additional Tests}

Time series analysis of the value premium for different $E Q$ quintiles

To investigate the role of earnings quality in contributing to the value premium further, we carry out a time series analysis of the value premium and how that varied across stocks with poor versus good earnings quality. We examine one year ahead buy-and-hold returns after the portfolio formation date $(\operatorname{Ret} 1)$, and track annual returns for the preceding three years, $R E T 0, R E T-1, R E T-2$, and for the following three years, $R E T 2$, RET3, RET4, for value and growth stocks. Table 6 reports the results. We find that growth stocks earn high returns in the three years leading up to the portfolio formation date (average returns of $0.232,0.270$, and 0.345 ) and lower returns for the following four years (average returns of $0.097,0.097,0.100$, and 0.111 ). Value stocks, on the other hand, have low returns in the three years leading up to the portfolio formation date $(0.059,0.090$ and -0.055$)$ followed by higher returns over the next four years $(0.157,0.150,0.145,0.136)$. These patterns of returns are more pronounced for the poorest earnings quality stocks (the highest $E Q$ quintile) than the highest earnings quality stocks (the lowest $E Q$ quintile). The patterns of returns are similar but the differential much weaker when looking at the high earnings quality stocks; growth stock returns between time 0 and 1 are the same as the increase in returns for value stocks over the same period. The results in table 6 provide further support to the argument that poor earnings quality contributes to the value premium primarily through the pricing of growth stocks.

\section{Asset pricing tests}

For completeness in assessing the role of earnings quality, we conduct asset pricing tests in the spirit of Fama and French (2015). Fama and French (2015) show that adding profitability $(R M W)$ and investment $(C M A)$ factors to the three factor model subsumes the power of the $S M B$ factor. We examine the incremental contribution of the earnings quality factor.

As in Fama and French (2015), we start with the three-factor model (market - MKT, size - $S M B$, and book to market - $H M L$ ) which is then augmented with profitability $(R M W)$ and investment $(C M A)$ factors. We then augment the three and five factor models by adding an earnings quality factor $(E Q F)$. The $E Q F$ factor is calculated as the excess return to the earnings quality factor portfolios, i.e., the average returns on two high earnings quality portfolios minus the average return on two low 
Earnings Quality and Book-to-Market in the Cross Section of Expected Returns 199

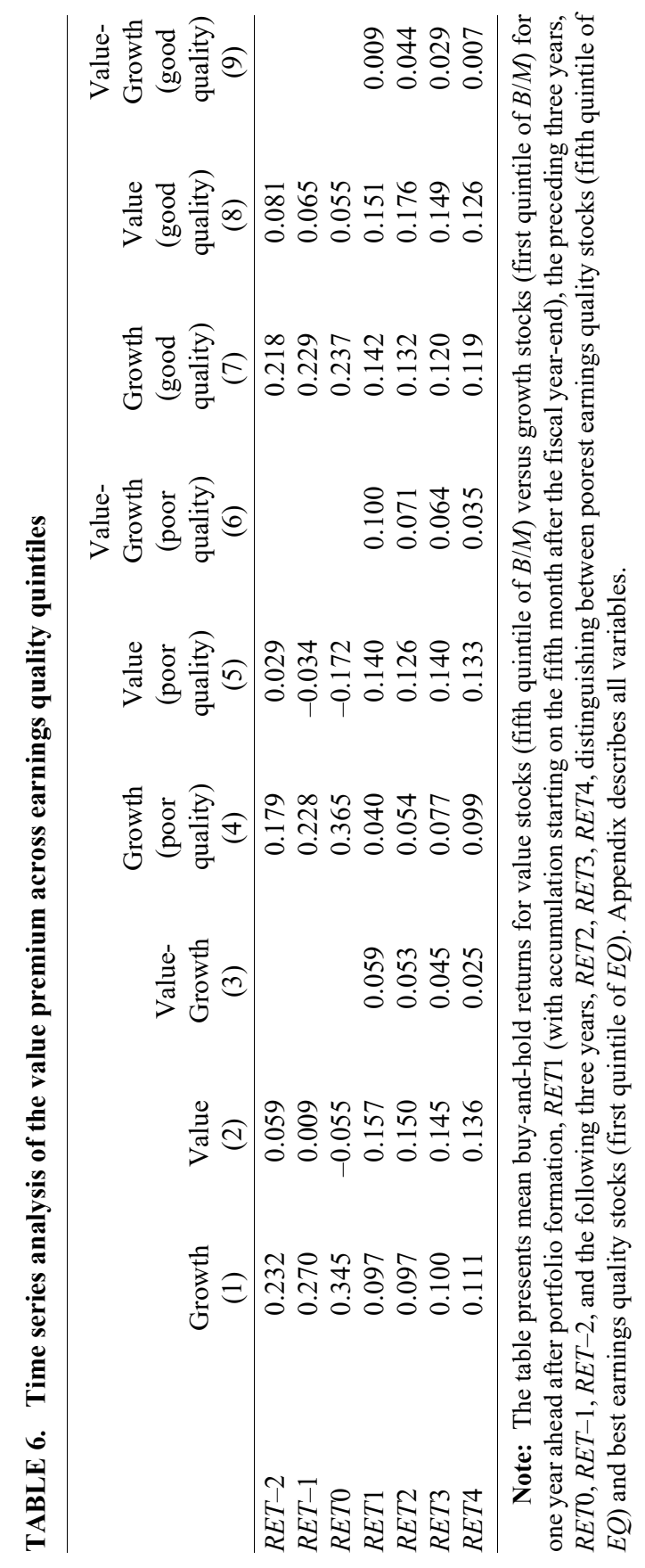


earnings quality portfolios. To estimate the $E Q F$ factor, we condition on size the same way Fama and French (2015) use to condition the $R M W$ and CMA factors. ${ }^{14}$ This allows us to directly control for the large correlation between firm size and earnings quality in the estimation process. $^{15}$

Table 7, Panel A, presents summary statistics of the monthly returns of all factors employed in the paper. $E Q F$ and $H M L$ have the lowest average returns, while $M K T$ has the highest average return, but also the highest standard deviation. Panel B reports two-way Pearson correlations between the various factors including the $E Q F$ factor. While all other factors are highly correlated and may give rise to econometric problems, the $E Q F$ factor exhibits low correlations, making it an interesting and worthwhile addition to the three and five factor models.

Table 7, Panel C, reports the findings on the performance of three, four, five and six-factor models. For the asset pricing tests, we use the unconstrained sample, i.e., the sample before deleting observations without analyst forecast data in order to improve comparability of the results to prior literature. To expand on the results reported in tables 5-6, the tests are for $25 B M-E Q$ portfolios. The first row is the three factor model; the second row is the three factor model augmented with the $E Q F$ factor; the third row is the five factor model; and the fourth row is the augmented five factor model with the $E Q F$ factor. For each factor model, we report the value of the Gibbons, Ross and Shanken (1989) GRS test, the average absolute value of the intercepts, the number of intercepts that are negative, the number of negative intercepts for growth firms that are significant and the GRS p-values. ${ }^{16}$

In the $B M-E Q$ portfolios, the average absolute intercept for the three factor model is 0.174 . Adding $E Q F$ shrinks this to 0.144 . In contrast, adding $R M W$ and $C M A$ to the three factor model reduces the average absolute intercept from 0.174 to 0.168 . Adding $E Q F$ to the five factor

14. See http://mba.tuck.dartmouth.edu/pages/faculty/ken.french/Data Library/f-f 5 factors $2 \times 3 . h$ html.

15. The correlation between firm size and earnings quality (smaller firms are associated with poor earnings quality) could lead to a spurious positive loading on the earnings quality factor. This could explain preliminary evidence on the pricing of earnings quality (Francis et al. 2005). To address this issue, Core, Guay and Verdi (2008, p.11) examine portfolios that condition on all size, book to market and earnings quality. We follow the approach of Fama and French (2015) and control for firm size when estimating factors.

16. The GRS statistic tests whether the expected values for all 25 intercept values are zero. 
TABLE 7. Tests of three-, four-, five- and six-factor models (368 months)

A. Summary statistics on factors

\begin{tabular}{lccccc} 
Factors & Mean & Std. & $Q 1$ & Median & $Q 3$ \\
\hline$M K T$ & 0.007 & 0.045 & -0.019 & 0.012 & 0.036 \\
$S M B$ & 0.002 & 0.029 & -0.013 & 0.000 & 0.017 \\
$H M L$ & 0.001 & 0.030 & -0.015 & 0.000 & 0.019 \\
$R M W$ & 0.004 & 0.026 & -0.008 & 0.004 & 0.014 \\
$C M A$ & 0.003 & 0.020 & -0.010 & 0.002 & 0.015 \\
$E Q F$ & 0.001 & 0.039 & -0.020 & -0.002 & 0.015
\end{tabular}

B. Pearson Correlations among factors

\begin{tabular}{lcccccr} 
& $M K T$ & $H M L$ & $S M B$ & $R M W$ & $C M A$ & $E Q F$ \\
\hline MKT & 1.000 & -0.239 & 0.194 & -0.370 & -0.390 & -0.028 \\
& & $<.0001$ & 0.000 & $<.0001$ & $<.0001$ & 0.591 \\
$H M L$ & 1.000 & -0.170 & 0.352 & 0.661 & 0.045 \\
& & & 0.001 & $<.0001$ & $<.0001$ & 0.387 \\
$S M B$ & & 1.000 & -0.459 & -0.071 & -0.099 \\
& & & $<.0001$ & 0.176 & 0.058 \\
$R M W$ & & & 1.000 & 0.193 & 0.038 \\
& & & & $<0.000$ & 0.470 \\
CMA & & & & 1.000 & 0.055 \\
& & & & & 0.289 \\
$E Q F$ & & & & & 1.000 \\
\hline
\end{tabular}

C. Regression Results

\begin{tabular}{lcccc}
$25 B M-E Q$ portfolios & $G R S$ & $A|a i|$ & $N$ negative (*) GRS p-values \\
\hline$S M B, H M L$ & 2.363 & 0.174 & $4(1)$ & 0.002 \\
$S M B, H M, E Q F$ & 2.355 & 0.144 & $8(2)$ & 0.002 \\
$S M B, H M L, R M W, C M A$ & 2.175 & 0.168 & $7(2)$ & 0.008 \\
$S M B, H M L, R M W, C M A, E Q F$ & 2.151 & 0.133 & $9(4)$ & 0.009
\end{tabular}

Note: The table provides summary statistics and tests the ability of three-, four-, fiveand six-factor models to explain monthly excess returns on $25 B M-E Q$ portfolios. For each set of 25 regressions, the table shows the factors that augment the $R m-R f(M K T)$ in the regression model, the GRS statistics testing whether the expected values of all 25 intercept estimates are zero, the average absolute value of the intercepts $A|a i|$, the number of ai that are negative (number of negative $a i$ for growth firms that are significant*) and the GRS test p-values. The $E Q F$ factor is calculated as the excess return to the earnings quality factor portfolios, i.e., the average returns on two high earnings quality portfolios ( $Q 1$ and $Q 2)$ minus the average return on two low earnings quality portfolios ( $Q 4$ and $Q 5)$. To estimate the $E Q F$ factor, we condition on size the same way Fama and French (2015) use to condition the $R M W$ and $C M A$ factors. $R M W$ is the excess return on the profitability portfolio (two robust operating profitability portfolios minus two weak operating profitability portfolios). $C M A$ is the excess return to investment (average returns on two conservative investment portfolios minus the average return on the two-aggressive investment portfolios), and $H M L$ is the return to book-to-market mimicking portfolio. 
model reduces the average absolute intercept from 0.168 to $0.133 .{ }^{17} \mathrm{In}$ other words, while adding $R M W$ and $C M A$ to the three factor model reduces the average absolute intercept by 6 basis points, adding $E Q F$ to the three factor model reduces it by 30 basis points. The $E Q F$ addition to the five factor model reduces the average absolute intercept by 35 basis points. Both relative to the three factor model and the five factor model, the average absolute intercept improves when we add the $E Q F$ factor. In our sample, the five factor model augmented by $E Q F$ is the best representation of asset prices.

The results in table 7 indicate that the five factor asset pricing model augmented with the $E Q F$ factor describes relatively better expected returns of portfolios based on independent sorts of stocks on $B M-E Q$. That is, EQF contributes to risk incrementally of $R M W$ and $C M A$ factors.

\section{Conclusion}

The purpose of this paper is to examine whether a value premium exists over our sample period and whether earnings quality contributes to the value premium. Our results confirm the existence of a value premium that is driven primarily by firms of poor earnings quality. We also show that poor earnings quality contributes to the premium primarily through the pricing of growth stocks. Incorporating common factors used in the literature to proxy for risk or behavioral biases as drivers of the value premium also shows that poor earnings quality contributes to the premium mainly as a source of behavioral biases of growth stocks.

Our study highlights the role that earnings quality plays within growth and value stocks, extending evidence on the role of profitability in shaping asset prices, to the role of the properties of reported earnings. By unraveling the effect of reported earnings quality on the value premium, our study highlights a channel through which behavioral biases shape the value premium. This insight is conceptually plausible with the subtle nature of managerial discretion embedded in earnings quality and echoes the need for future research to explore more the behavioral biases inducing effect of earnings quality on asset pricing. An important implication of our findings for investment strategies is the need to consider the effects of earnings quality, alongside other risk and behavioral factors.

Accepted by: Prof. P. Theodossiou, PhD, Editor-in-Chief, October 2019

17. All intercept values are expressed in per cent per month. 
Appendix. Definition of variables in alphabetical order

\begin{tabular}{|c|c|}
\hline Variable & Description \\
\hline ADispersion & $\begin{array}{l}\text { Standard deviation of individual analyst earnings forecasts issued } \\
\text { during the fiscal year, divided by stock price at year } t-1 \text {. }\end{array}$ \\
\hline$A b s A A$ & Absolute abnormal accruals based on the Jones (1991) model. \\
\hline$A Q$ & $\begin{array}{l}\text { The standard deviation of the firm's residuals from years } t-4 \text { to year } \\
t \text { from annual cross-sectional estimations of the modified Dechow } \\
\text { and Dichev (2002) model, i.e., regressions of the firm's year } t \\
\text { working capital accruals }(T C A) \text { on year } t, t-1 \text {, and } t+1 \text { cash flows } \\
\text { from operations }(C F O) \text {, the year } t \text { change in revenues }(\triangle R E V) \text { and } \\
\text { the year } t \text { property, plant, and equipment }(P P \& E) \text { (all variables } \\
\text { scaled by average total assets), where the regression is estimated } \\
\text { using data from } t=1961-2010 \text {. Because of the lead term in cash } \\
\text { flows from operations the measure is lagged one year to ensure there } \\
\text { is no conditioning on future information. }\end{array}$ \\
\hline$B / M$ & $\begin{array}{l}\text { Book value of equity divided by the market value of equity at the end } \\
\text { of the fourth month after the firm's fiscal year-end. }\end{array}$ \\
\hline$C M A$ & $\begin{array}{l}\text { The excess return to investment (average returns on two conservative } \\
\text { investment portfolios minus the average return on the two-aggressive } \\
\text { investment portfolios) (Fama and French 2015). }\end{array}$ \\
\hline$E Q(Q)$ & A measure based on the quintiles by year of the $E Q$ factor. \\
\hline |Forecast error $\mid$ & $\begin{array}{l}\text { The absolute difference between actual EPS (I/B/E/S actual EPS) and } \\
\text { the first analyst consensus forecast for year } t \text { issued at the beginning } \\
\text { of the period scaled by stock price at year } t-1 \text {. }\end{array}$ \\
\hline Analyst coverage & Number of analysts following the firm. \\
\hline EarnVar & $\begin{array}{l}\text { Standard deviation of the firm's net income before extraordinary } \\
\text { items (NIBE) scaled by total assets over years } t-5 \text { to } t \text {. }\end{array}$ \\
\hline$E Q$ & $\begin{array}{l}\text { We use a combined measure of earnings quality based on the } \\
\text { common factor, } E Q \text {, identified by factor analysis performed on three } \\
\text { measures of earnings quality: a) earnings variability (EarnVar); b) } \\
\text { accruals quality }(A Q) \text {; and c) absolute abnormal accruals }(A b s A A) \text {. }\end{array}$ \\
\hline$E Q F$ & $\begin{array}{l}\text { The } E Q F \text { factor is calculated as the excess return to the earnings } \\
\text { quality factor portfolios, i.e., the average returns on two high } \\
\text { earnings quality portfolios (Q1 and } \mathrm{Q} 2 \text { ) minus the average return on } \\
\text { two low earnings quality portfolios (Q4 and Q5). To estimate the } \\
E Q F \text { factor, we condition on size the same way Fama and French } \\
\text { (2015) use to condition the } R M W \text { and } C M A \text { factors. }\end{array}$ \\
\hline$H M L$ & $\begin{array}{l}\text { The return to book-to-market mimicking portfolio (Fama and French } \\
\text { 1993). }\end{array}$ \\
\hline
\end{tabular}


Appendix. (Continued)

\begin{tabular}{ll}
\hline Variable & $\begin{array}{l}\text { Description } \\
\text { IVol }\end{array}$ \\
& $\begin{array}{l}\text { Idiosyncratic stock return volatility calculated as the standard } \\
\text { deviation of daily abnormal stock returns. We obtain abnormal } \\
\text { returns as the residuals from regressing the company's daily stock } \\
\text { returns adjusted for the risk free rate on the market premium. }\end{array}$ \\
Log $(M k t C a p)$ & $\begin{array}{l}\text { Natural log of the firm's market capitalization four months following } \\
\text { the fiscal year end. }\end{array}$ \\
MKT & $\begin{array}{l}\text { The excess return on the market portfolio. } \\
\text { Price }\end{array}$ \\
Stock price at the end of the forth month following the calendar \\
year-end. \\
The excess return on the profitability portfolio (two robust operating \\
profitability portfolios minus two weak operating profitability \\
portfolios) (Fama and French 2015). \\
Annual buy-and-hold returns for each firm for the year after the \\
portfolio is formed, i.e., the twelve months starting on the fifth month \\
after the calendar year-end. \\
The return to size factor-mimicking portfolio (Fama and French \\
1993).
\end{tabular}

\section{References}

Ackert, L. F., and Athanassakos, G. 2003. A Simultaneous Equation Analysis of Analysts' Forecast Bias, Analyst Following and Institutional Ownership. Journal of Business, Finance and Accounting September/October: 1017-1041.

Ackert, L. F., and Athanassakos, G. 1997. Prior uncertainty, analyst bias and subsequent abnormal returns. The Journal of Financial Research 20(2): 263-273.

Adrian, T., and Franzoni, F. 2005. Learning about beta: Time varying factor loadings, expected returns and the conditional CAPM. Journal of Empirical Finance 16(4): 538-556.

Ang, A., and Chen, J. 2007. CAPM over the long run: 1926-2001. Journal of Empirical Finance 14(1): 1-40.

Ang, A.; Hodrick, R. J.; Xing, Y.; and Zhang, X. 2006. The cross-section of volatility and expected returns. The Journal of Finance 61(1): 259-299.

Ashbaugh, H.; Collins, D.; and LaFond, R. 2006. The effects of corporate governance on firms credit ratings. Journal of Accounting and Economics 42(1-2): 203-243.

Asness, C.; Frazzini, A.; Israel, R.; and Moskowitz, T. 2014. Fact, fiction and value investing. The Journal of Portfolio Management 40(5): 75-92. 
Athanasakou, V., and Olsson, P. 2019. Managerial discretion and firm fundamentals. Working paper available at https://ssrn.com/abstract= 2715636.

Athanassakos, G. 2009. Value vs. Growth Stock Returns and the Value Premium: The Canadian Experience 1985-2005. Canadian Journal of Administrative Studies 26(2): 109-129.

Athanassakos, G. 2011. The Performance, Pervasiveness and Determinants of Value Premium in Different US Exchanges: 1986-2006. Journal of Investment Management 93, Third Quarter: 33-73.

Ball, R.; Gerakos, J.; Linnainmaa, J.; and Nikolaev, V. 2016. Accruals, cash flows and operating profitability in the cross section of stock returns. Journal of Financial Economics 121(1): 28-45.

Ball, R.; Gerakos, J.; Linnainmaa, J.; and Nikolaev, V. 2019. Earnings, retained earnings, and book-to-market in the cross section of expected returns. Journal of Financial Economics (Forthcoming).

Barberis, N., and Shleifer, A. 2003. Style Investing. Journal of Financial Economics 68: 161-199.

Barton, J., and Simko, P. J. 2002. The Balance Sheet as an Earnings Management Constraint. The Accounting Review 77: 1-33.

Basu, S. 1977. Investment Performance of Common Stocks in Relation to Their Price to earnings Ratios: A Test of the Efficient Market Hypothesis. Journal of Finance 32: 663-682.

Beneish, M. 1997. Detecting GAAP violation, implications for assessing earnings management among firms with extreme financial performance. Journal of Accounting Public Policy 16(3): 271-309.

Bharath, S.; Sunder, J.; and Sunder, S. 2008. Accounting quality debt contracting. The Accounting Review 83(1): 1-28.

Bhushan, R. 1989. Firm characteristics and analyst following. Journal of Accounting and Economics 11: 255-274.

Brav, A.; Heaton, J. B.; and Li, S. 2010. The limits of the limits of Arbitrage. Review of Finance 14: 157-187.

Callen, J. L.; Khan, M.; and Lu, H. 2013. Accounting quality, stock price delay, and future stock returns. Contemporary Accounting Research 30(1): 269295.

Cao, N. V. 2015. What explains the value premium? The case of adjustment costs, operating leverage and financial leverage. Journal of Banking and Finance 59: 350-366.

Chan, L. K. C., and Lakonishok, J. 2004. Value and Growth Investing: Review and Update. Financial Analysts Journal January/February: 71-84.

Chan, L. K. C.; Hamao, Y.; and Lakonishok, J. 1991. Fundamentals and Stock Returns in Japan. Journal of Finance 46: 1739-1764.

Chaves, D. B.; Hsu, J. C.; Kalesnki, V.; and Shim, Y. 2013. What Drives the Value Premium? Risk versus Mispricing: Evidence from International Markets. Journal of Investment Management 11(4), Fourth Quarter: 1-18. 
Chen, C.; Huang, A. G.; and Jha, R. 2012. Idiosyncratic return volatility and the information quality underlying managerial discretion. Journal of Financial and Quantitative Analysis 47(4): 873-899.

Chen, J.; Hou, K.; and Stulz, R. 2015. Are Firms in Boring Industries Worth Less?, Working Paper, Fisher College of Business, Ohio State University, January.

Chen, L. H.; Dhaliwal, D.; and Trombley, M. A. 2008. The effect of fundamental risk on the market pricing of accruals quality. Journal of Accounting Auditing and Finance 23(4): 471-492.

Cheong, F., and Thomas, J. 2011. Why do EPS forecast error and dispersion not vary with scale? Implications for analyst and managerial behavior. Journal of Accounting Research 49: 359-401.

Chichernea, D.; Holder, A. D.; and Wei, D. 2012. Connecting the dots: the accruals quality premium vs the value premium. Managerial Finance 38(12): 1106-1133.

Cohen, D. A., and Zarowin, P. 2010. Accrual-based and real earnings management activities around seasoned equity offerings. Journal of Accounting and Economics 50: 2-19.

Cohen, R. B.; Polk, C.; and Vuolteenaho, T. 2003. The Value Spread. Journal of Finance 58: 609-641.

Core, J. E.; Guay, W. R.; and Verdi, R. 2008. Is accruals quality a priced risk factor? Journal of Accounting and Economics 46: 2-22.

D’Avolio, G. 2002. The Market for Borrowing Stocks. Journal of Financial Economics 66: 271-306.

Dechow, P. M.; Ge, W.; and Schrand, C. 2010. Understanding earnings quality: A review of the proxies, their determinants and their consequences. Journal of Accounting and Economics 50: 344-401.

Dechow, P. M., and Dichev, I. D. 2002. The quality of accruals and earnings: The role of accrual estimation errors. The Accounting Review 77, Supplement: 35-59.

Dechow, P. M.; Kothari, S. P.; and Watts, R. L. 1998. The relation between earnings and cash flows. Journal of Accounting and Economics 25: 133168.

Desai, H.; Rajgopal, S.; and Vehkatachalam, M. 2004. Value-glamour and accruals mispricing. One anomaly or two? The Accounting Review 79(2): 355-385.

Dichev, I. D., and Tang, V. W. 2009. Earnings volatility and earnings predictability. Journal of Accounting and Economics 47(1-2): 160-181.

Dichev, I. D., and Tang, V. W. 2008. Matching and the changing properties of accounting earnings over the last 40 years. The Accounting Review 83(6): 1425-1460.

Diether, K. B.; Malloy, C. J.; and Scherbina, A. 2002. Differences of opinion and the cross section of stock returns. The Journal of Finance 57(5): 2113-2141. 
Doukas, J. A.; Kim, C. F.; and Pantzalis, C. 2004. Divergent opinions and the performance of value stocks. Financial Analysts Journal 60(6): 55-63.

Easley, D., and O'Hara, M. 2004. Information and the cost of capital. The Journal of Finance 59(4): 1553-1583.

Easley, D.; Hvidkjaer, S.; and O'Hara, M. 2002. Is information risk a determinant of asset returns? Journal of Finance 57: 2185-2221.

Fairfield, P., and Whisenant, J. S. 2001. Using fundamental analysis to assess earnings quality: Evidence from the Center for Financial Research and Analysis. Journal of Accounting Auditing and Finance 16(4): 273-295.

Falkenstein, E. G. 1996. Preferences for Stock Characteristics as Revealed by Mutual Fund Portfolio Holdings. Journal of Finance 51: 111-135.

Fama, E. F., and French, K. R. 1992. The Cross Section of Expected Stock Returns. Journal of Finance 47: 427-465.

Fama, E. F., and French, K. R. 1993. Common Risk Factors in the Returns on Stocks and Bonds. Journal of Financial Economics 33: 3-56.

Fama, E. F., and French, K. R. 1996. Multifactor Explanations of Asset Pricing Anomalies. Journal of Finance 51: 55-84.

Fama, E. F., and French, K. R. 1995. Size and Book-to-Market Factors in Earnings and Returns. Journal of Finance 50: 131-155.

Fama, E. F., and French, K. R. 2015. The Five Factor Asset Pricing Model. Journal of Financial Economics 11(6): 1-22.

Fama, E. F., and French, K. R. 1998. Value versus growth: The international evidence. The Journal of Finance 53(6): 1975-1999.

Fama, E. F., and MacBeth, J. D. 1973. Risk, Return and Equilibrium: Empirical Tests. Journal of Political Economy 81(3): 607-636.

Fan, S.; Opsal, S.; and Yu, L. 2015. Equity anomalies and idiosyncratic risk around the world. Multinational Finance Journal 19(1): 33-75.

Fields, T. D.; Lys, T. Z.; and Vincent, L. 2001. Empirical research on accounting choice. Journal of Accounting and Economics 31: 255-307.

Fisher, G.; Shah, R.; and Titman, S. 2016. Analyst long-term growth forecasts, accounting fundamentals and stock returns. Working paper Available at SSRN: Available at SSRN: https://ssrn.com/abstract=2759332.

Francis, J.; LaFond, R.; Olsson, P.; and Schipper, K. 2005. The market pricing of accruals quality. Journal of Accounting and Economics 39(2): 295-327.

Francis, J.; Nanda, D.; and Olsson, P. 2008. Voluntary disclosure, earnings quality, and cost of capital. Journal of Accounting Research 461: 53-99.

Francis, J.; Olsson, P.; and Schipper, K. 2006. Earnings quality. Foundations and Trends in Accounting 1: 4.

Francis, J.; Lafond, R.; Olsson, P.; and Schipper, K. 2004. Costs of equity and earnings attributes. The Accounting Review 79(4): 967-1010.

Gibbons, M.; Ross, S.; and Shanken, J. 1989. A test of the efficiency of a given portfolio. Econometrica 57: 1121-1152.

Gompers, P. A., and Metrick, A. 2001. Institutional investors and equity prices. The Quarterly Journal of Economics 116: 229-259. 
Graham, J. R.; Li, S.; and Qiu, J. 2008. Corporate misreporting and bank loan contracting. Journal of Financial Economics 891: 44-61.

Greenwald, B. C. N.; Kahn, J.; Sonkin, P. D.; and Van Biema, M. 2001. Value Investing: From Graham to Buffett and Beyond, Wiley Finance, John Wiley \& Sons, Inc., Hoboken, N.J.

Gunny, K. A. 2010. The relation between earnings management using real activities manipulation and future performance: Evidence from meeting earnings benchmarks. Contemporary Accounting Research 27(3): 855-888.

Guo, H.; Savickas, R.; Wang, Z.; and Yang, J. 2009. Is the value premium a proxy for time varying investment opportunities: Some time series evidence. Journal of Financial and Quantitative Analysis 44(1): 133-154.

Hirshleifer, D.; Lim, S. S.; and Teoh, S. H. 2011. Limited Investor Attention and Stock Market Misreactions to Accounting Information. The Review of Asset Pricing Studies 1(1): 35-73.

Hirshleifer, D.; Hou, K.; Teoh, S. H.; and Zhang, Y. 2011. Do Investors Overvalue Firms with Bloated Balance Sheets? Journal of Accounting and Economics (38): 297-331.

Hou, K., and Loh, R. 2016. Have we solved the idiosyncratic volatility puzzle? Journal of Financial Economics 121(1): 167-194.

Houmes, R. E., and Skantz, T. R. 2010. Highly Valued Equity and Discretionary Accruals. Journal of Business, Finance and Accounting 37(1): 60-92.

Hu, N.; Dong, Y.; Liu, L.; and Yao, L. J. 2013. Not all that glitters is gold: the effect of attention and blogs on investors' investing behaviors. Journal of Accounting, Auditing and Finance 28(1): 4-19.

Hwang, S., and Rubesam, A. 2013, A behavioral explanation of the value anomaly based on time-varying return. Journal of Banking and Finance 37: 2367-2377.

Jensen, M. 2005. Agency Costs of Overvalued Equity. Financial Management 34: 5-19.

Jones, J. 1991. Earnings management during import relief investigations. Journal of Accounting Research 292:193-228.

Kapadia, N. 2011. Tracking down distress risk. Journal of Financial Economics 102: 167-182.

Kothari, S. P.; Shanken, J.; and Sloan, R. G. 1995. Another Look at the Cross Section of Expected Stock Returns. Journal of Finance 50: 185-224.

Kumnar, A., and Lee, C. 2006. Retail investor sentiment and return co-movements. Journal of Finance 64: 2451-2486.

La Porta, R.; Lakonishok, J.; Shleifer, A.; and Vishny, R. 1997. Good news for value stocks: further evidence on market efficiency. The Journal of Finance 52(2): 859-874.

Lakonishok, J.; Shleifer, A.; and Vishny, R. W. 1994. Contrarian Investment, Extrapolation and Risk. Journal of Finance 49: 1541-1578.

Lee, C. W. J.; Li, L. Y.; and Yue, H. 2006. Performance, growth and earnings 
management. Review of Accounting Studies 112: 305-334.

Lewellen, J., and Nagel, S. 2006. The conditional CAPM does not explain asset pricing anomalies. Journal of Financial Economics 82: 289-14.

Li, X.; Brooks, C.; and Miffre, J. 2009. The value premium and time carrying idiosyncratic risk. Journal of Business Finance and Accounting 369: 1252-1272.

Loughran, T. 1997. Book-to-market across firm size, exchange, and seasonality: Is there an effect? Journal of Financial and Quantitative Analysis 32(3): 249-268.

Malkiel, B. 1982. Risk and Return: A New Look, In The Changing Role of Debt and Equity in Financing US Capital Formation, Edited by B. Friedman, National Bureau of Economic Research, Chicago, IL: University of Chicago Press.

McNichols, M. F. 2002. Discussion of the quality of accruals and earnings: the role of accrual estimation errors. The Accounting Review 77, Supplement: 61-69.

Merton, R. 1987. A simple model of capital market equilibrium with incomplete information. Journal of Finance 42: 483-510.

Miller, E. M. 1977. Risk, uncertainty and divergence of opinion. The Journal of Finance 32(4): 1151-1168.

Nam, S.; Brochet, F.; and Ronen, J. 2012. The predictive value of accruals and consequences for market anomalies. Journal of Accounting, Auditing and Finance 27(2): 151-176.

John Neter, J., and Wasserman, W. 1974. Applied linear statistical models: Regression, analysis of variance, and experimental designs. Homewood, Illinois, Richard D. Irwin, Inc.

Novy-Marx, R. 2013. The other side of value: The gross profitability premium. Journal of Financial Economics 108: 1-28.

O'Hara, M. 2003. Presidential address: Liquidity and price discovery. Journal of Finance 58: 1335-1354.

Petkova, R., and Zhang, L. 2005. Is value riskier than growth? Journal of Financial Economics 78: 187-202.

Phalippou, L. 2008. Where is the Value Premium? Financial Analysts Journal 64 March: 41-48.

Piotroski, J. D., and So, E. C. 2012. Identifying expectations errors in value/glamour strategies: A fundamental analysis approach. Review of Financial Studies 25: 2841-2875.

Rajgopal, S., and Venkastachalam, M. 2011. Financial reporting quality and idiosyncratic return volatility. Journal of Accounting and Economics 51: $1-20$.

Richardson, S.; Tuna, I.; and Wysocki, P. 2010. Accounting anomalies and fundamental analysis: A review of recent research advances. Journal of Accounting and Economics 50(2-3): 410-454.

Roychowdhury, S. 2006. Earnings management through real activities 
manipulation. Journal of Accounting and Economics 42(3): 335-370.

Skinner, D. J., and Sloan, R. G. 2002. Earnings surprises, growth expectations, and stock returns or don't let an earnings torpedo sink your portfolio. Review of Accounting Studies 7(2-3): 289-312.

Sloan, R. G. 1996. Do stock prices fully reflect information in accruals and cash flows about future earnings? The Accounting Review 71: 289-315.

Vassalou, M., and Xing, Y. 2004. Default risk in equity returns. Journal of Finance 59: 831-868.

Walkshausl, C. 2016. Expectation errors in European value-growth strategies. Review of Finance 21(2): 845-870.

Xie, H. 2001. The mispricing of abnormal accruals. The Accounting Review 76: 357-373.

Zhang, C. 2010. A reexamination of the causes of time-varying stock return volatilities. Journal of Financial and Quantitative Analysis 45(3): 663-684.

Zhang, F. X. 2006. Information uncertainty and stock returns. The Journal of Finance 61(1): 105-137.

Zhang, L. 2005. The value premium. The Journal of Finance 60(1): 67-103. 